\title{
Microsedimentology of tills near Ainet, Austria - were palaeo-ice streams in the European Alps underlain by soft deforming bed zones?
}

\author{
Jürgen M. REITNER ${ }^{1 *} \&$ John MENZIES² \\ 1) Geologische Bundesanstalt /Geological Survey of Austria, Neulinggasse 38, A-1030 Wien, Austria \\ 2) Department of Earth Sciences, Brock University, St. Catharines, Ontario, L2S 3A1 Canada \\ * corresponding author: Juergen.Reitner@geologie.ac.at
}

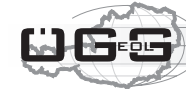

KEYWORDS

Glacial sedimentology, deformable bed, paleogeography, Last Glacial Maximum, Alpine Lateglacial, Eastern Alps

\begin{abstract}
Fast moving palaeo-ice masses within the European Alpine Ice Cap (EAIC) during the Last Glacial Maximum within the large valleys of the European Alps are likely comparable in terms of their subglacial conditions to ice streams that drained the larger Quaternary Ice Sheets in Europe and North America. Unlike these continental-style ice sheets, the ice inundating the European Alps, like the Cordilleran Ice Sheet in North America, flowed through confined bedrock valleys that, at close to the glacial maximum, acted in a similar manner to ice streams. Little mention exists as to the extent of soft sediment basal deformation in these deep valleys although increasingly such conditions are known from several parts of the EAIC. The Drau (Drava) ice stream during the Alpine Last Glacial Maximum (=Würmian Pleniglacial, $\sim 29-\sim 20 \mathrm{ka}$ ) as well as small tributary glacier during the early Lateglacial phase of ice decay $(\sim 20-19 \mathrm{ka})$ appears as a temperate, fast-moving ice mass that would likely be underlain by soft deforming sediment. It is the underlying microsedimentology of parts of the Drau Valley catchment in the Lienz area of Austria that is the focus of this paper. The tills in the Isel Valley at Ainet reveal a detailed depiction of soft sediment deformation processes throughout the basal zones of this ice stream illustrative of temperate basal ice conditions and comparable to those tills of northern Austria under the Inn Ice Stream. The tills exhibit the characteristics of ongoing active soft-sediment deformation. The evidence from Ainet supports the contention that most likely subglacial processes beneath ice streams in the palaeo-EAIC were comparable to those today in Antarctica and in the Quaternary ice streams of the Cordilleran, Laurentide and North European Ice Sheets.
\end{abstract}

\section{Introduction}

Subglacial conditions beneath fast moving ice masses within the European Alpine Ice Cap (EAIC) during the Last Glacial Maximum within the large valleys of the European Alps can be compared to ice streams that drained the larger Quaternary Ice Sheets in Northern Europe and especially the Cordilleran Ice Sheet in North America and the modern East and West Antarctic Ice Sheets. Unlike many of these continental-style ice sheets, the ice inundating the European Alps, as in the case of the Cordilleran Ice Sheet in western North America (Clague and Ward, 2011; Margold et al., 2013; Seguinot et al., 2016; Eyles et al., 2018), flowed first through confined bedrock valleys. The Alpine glaciers acted close to the glacial maximum in a manner similar to ice streams in the North American Cordilleran Ice Sheet (Dowdeswell and Elverhøi, 2002; Walter et al., 2014; Seguinot et al., 2016, 2018; Cohen et al., 2018; Eyles et al., 2018; Stokes, 2018). Understanding subglacial conditions beneath ice streams remains incomplete (Cowan et al., 2012, 2014; Walter et al., 2014; Davies et al., 2018; Eyles et al., 2018; Narloch et al., 2020). The geological and rheological environments of ice stream beds play key roles in overall ice sheet dynamics. Evidence suggests that the presence of deformable basal sediments is a necessary pre-condition for fast-flowing ice streams (Winsborrow et al., 2010; Brisbourne et al., 2017; Diez et al., 2018). Such sediments sustain subglacial till layers, which if water saturated and under high porewater pressure provide little resistance to ice flow (Reinardy et al., 2011; Reinardy, 2010; Gao et al., 2012; Menzies et al., 2013; Smith et al., 2013). An improved knowledge of the subglacial environments may also illuminate controls in basal ice activity in terms of overall ice sheet mass balance based upon a grasp of basal ice conditions. Thermal regimes, sediment availability and rheology, as well as subglacial hydrology, may elucidate controls on ice dynamics in terms of ice sheet mass balance based on basal thermal regimes, sediment flux and rheology leading to more 'sophisticated', reliable and verifiable models of fast confined ice flow in mountain terrains (see Diez et al., 2018 and references therein).

In considering active subglacial processes beneath the European Alpine Ice Cap at the Alpine Last Glacial Maximum (AlpLGM), the model of Seguinot et al. (2018) 
indicates that around 50 ice streams can probably be considered to have emanated from the inner regions of the mountain massif toward the margins (Ehlers et al., 2011; van Husen, 1987, 2000). The high topographic relief of the Alps likely forced ice flowing out from the ice cap's inner zone through long outlet valleys where higher basal ice velocities enhanced by topographic constriction, explains their occurrence (Haeberli and Penz, 1985; Cohen et al., 2018). However, debate continues as to basal ice temperatures and sliding velocities, as well as basal interface conditions whether on hard or soft beds in many inner and marginal zones of EAIC (Lindgren et al., 2016; Cohen et al., 2018). Little mention exists as to the extent of soft sediment basal deformation although increasingly such conditions are known from several parts of the EAIC (Menzies and Reitner, 2016, 2019; Büchi et al., 2017).

The Drau (Drava) ice stream was selected as one of possibly many such streams emanating from the EAIC that can be defined by the presence of confined streamlined flow where evidence of subglacial streamlining can be observed (Stumpf et al., 2000; Clark and Stokes, 2003; Andreassen and Winsborrow, 2009: Stokes, 2011, 2018; Menzies and Reitner, 2016; Eyles et al., 2018) The Drau, when modelled, appears as a fast-moving ice mass that would likely be underlain by soft deforming sediment (Seguinot et al., 2018, fig. 4a). It is the underlying microsedimentology of parts of the Drau Valley in the Lienz area of Austria that is the focus of this paper and from which an increased understanding of the sedimentological signature of these inner valleys beneath ice streams may be obtained and augmented (Menzies et al., 2013; Menzies and Reitner, 2016; Burschil et al., 2019). This work stems from and builds upon recent research in northern Austria in the tributary side valleys of the Inn Ice Stream in which soft deformation microstructures and rapid changes in localized stress levels can be distinguished within the subglacial tills. Similarly, these northern Austria tills illustrate the effect of warm based subglacial sediment deformation associated with an array of microstructures that are known to exist in many other subglacial tills in northern Europe, Antarctica, and North America (Cowan et al., 2012, 2014; Rice et al., 2014, 2018; Menzies and van der Meer, 2018). The microstructures present within the tills at Ainet reveal, for the first time, a complex history of microfabric development resulting from ductile shearing and brittle deformation during the emplacement processes under fast ice stream conditions.

\section{Geological and geomorphological background}

The study site at Ainet (Figs. 1, 2) is in the Schobergruppe range which represents the southern flank of the Hohen Tauern mountains in Eastern Tyrol (Austria). The Ainet site is part of the lower, downstream end of the Daber Valley, a tributary valley of the Isel Valley to the northwest of the city of Lienz, which is part of the Drau river catchment (Burschil et al., 2019). The present-day unglaciated catchment reaches from cirques surrounded by $\geq 3000 \mathrm{~m}$ high peaks down to the floor of the Isel Valley at $700 \mathrm{~m}$ a.s.l.
Geologically, the Schobergruppe range consists of crystalline rocks of the Koralpe-Wölz nappe system of the Austroalpine Superunit (Linner et al., 2013). The Daber Valley catchment is predominantly composed of eclogite partly retrograded to amphibolite in its upper part, and paragneiss and micaschist in the middle and lower parts. During the AlpLGM, the Ainet area was part of the accumulation zone of the glacier complex of the Eastern Alps with the Isel Glacier as the dominant branch of the Drau Glacier. The ice surface, in the valley sector of Ainet, based on trimline evidence was located at 2200-2300 m (Reitner, 2003) with a surface slope of the glacier along the valley axis in the range of $0.4-0.5 \%\left(0.2^{\circ}-0.3^{\circ}\right)$, based on
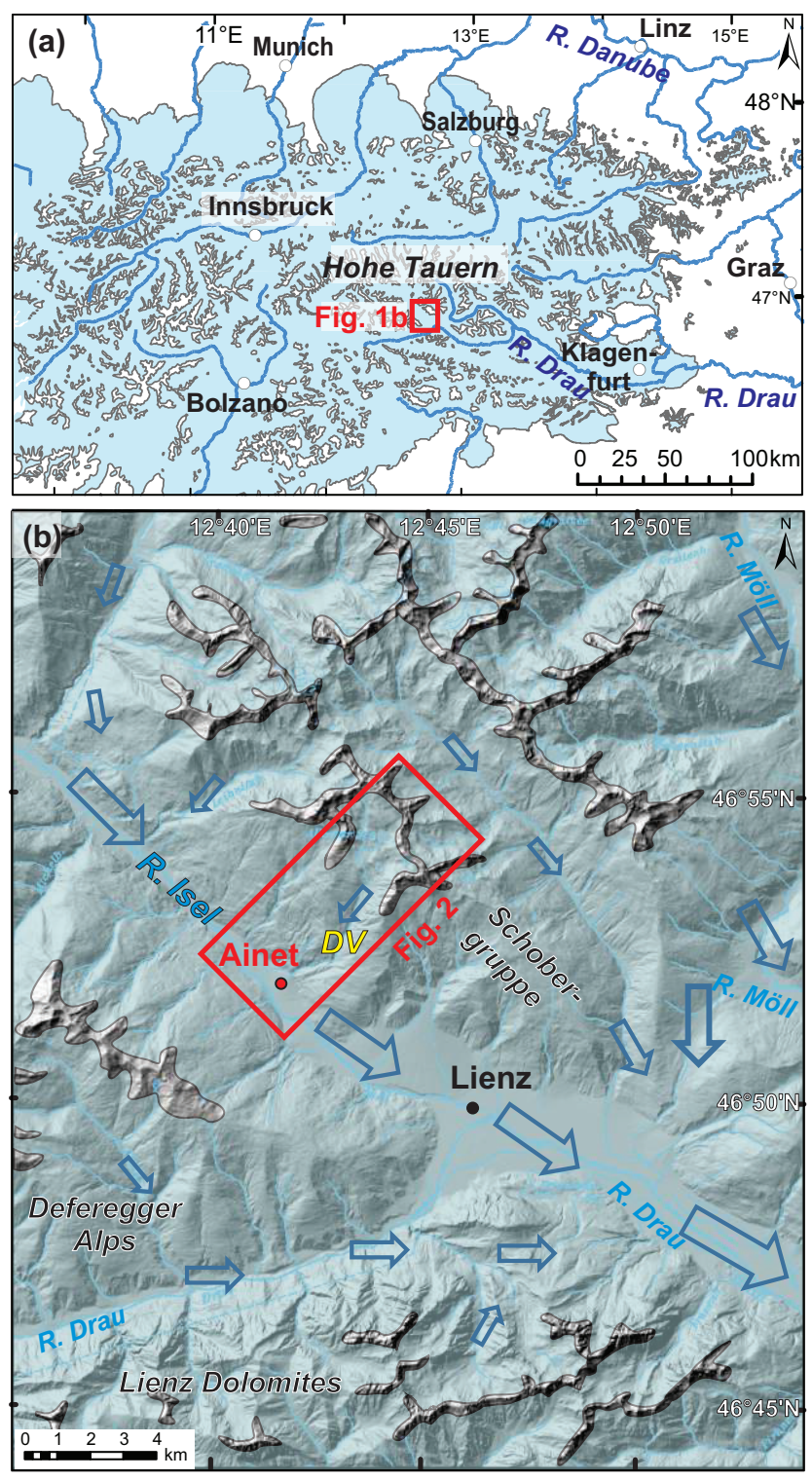

Fig. 1: (a) Location of the study area around Lienz in the centre of the Eastern Alps. The AlpLGM ice extent (in pale blue; based on Ehlers et al., 2011). (b) Map of the Lienz area with the village of Ainet in the Isel Valley as well as the tributary Daber Valley (DV). The extent of the geological map in Fig. 2 is shown by the red rectangle. The transparent pale blue area indicates the glacier-covered area during the climax of the AIpLGM with blue arrows showing ice-flow directions. Only the highest peaks (in grey) were nunataks (modified after Reitner et al., 2016). 
reconstructions by van Husen (1987) and Reitner (2003). The results of glacial erosion are evident on the flanks of the Isel Valley with moulded surfaces, roches moutonnées and oversteepened slopes which are partly characterised by deep-seated mass movements (Reitner and Linner, 2009). The most impressive evidence of glacial erosion is the overdeepened Lienz Basin (c. $600 \mathrm{~m}$ depth, Burschil et al., 2019) which most likely extends $10 \mathrm{~km}$ upstream to the Ainet site (Reitner and Linner, 2009).

The sedimentary sequence of Ainet site (Fig. 3a) is located on a prominent ridge east of the lower Daber Valley and consists of glacial and fluvioglacial deposits reaching from $800 \mathrm{~m}$ to $1300 \mathrm{~m}$ a.s.l. (Reitner, 2003). These deposits can be subdivided in unconformity-bounded (allostratigraphic) units (Reitner et al., 2016). Based on the regional geological setting, the lower till (Isel unit) represents a subglacial deposit of the Isel Glacier during the AlpLGM (= Würmian Pleniglacial) (van Husen and Reitner, 2011) lasting from 29 - 20 ka with a climax around 27 - 20 ka (Monegato et al., 2007). Delta deposits (Ainet unit) and the upper till (Daber unit) are typical of the early Lateglacial phase of ice-decay occurring around $19 \mathrm{ka}$ (Klasen et al., 2007; Reitner, 2007; Wirsig et al., 2016). Together with the evidence of the two younger lateglacial phases of glacier activity (Gschnitz stadial $17-16 \mathrm{ka}$, and Egesen stadial; $12.9-11.7 \mathrm{ka}$ ) in the upper valley (Fig. 2), the sedimentary succession of Ainet represents the most complete glacial sequence of the Late Würmian ( 29 - $11.7 \mathrm{ka})$ and of the Alpine Lateglacial ( $19-11.7 \mathrm{ka})$ south of the Hohen Tauern mountain chain (Reitner et al., 2016).

\section{Methods}

Till samples obtained at the Ainet site were in exposures high above the village and taken from the eastern side of the valley (Figs. 2, 3a). Both exposures, at sites $A$ and $B$, were bulk sampled and sampled for micro-sedimentology, and were over 4 metres in height with a total of 10 larger samples taken for micro-morphological analyses ( 5 at each site) (Figs. 4a, 4b). Samples Al- 1 to Al- 4 were from the Daber unit (early Lateglacial phase of ice-decay) at site $\mathrm{B}$, whereas samples Al-5 to Al-10 were from the older Isel unit (AlpLGM) at site A (Table 1). All lithofacies descriptions were done based on Eyles and Miall (1984) and Keller (1996). The bulk samples (sites A to D) were obtained for grain-size analyses, clast shape and lithology (sample size $>10 \mathrm{~kg}$ ) and analyzed according to Reitner (2005) and Reitner et al. (2010).

\subsection{Field sampling}

In order to obtain a series of subsamples for thin section analyses, samples were obtained from disturbance-free cleaned vertical exposures using Kubiëna tins or as bulk samples where necessary, then transported, and prepared for resin impregnation using standard micro-morphological techniques (Rice et al., 2014, 2018; Menzies and van der Meer, 2018). Sampling was carried out on a sediment exposure face cleaned parallel to

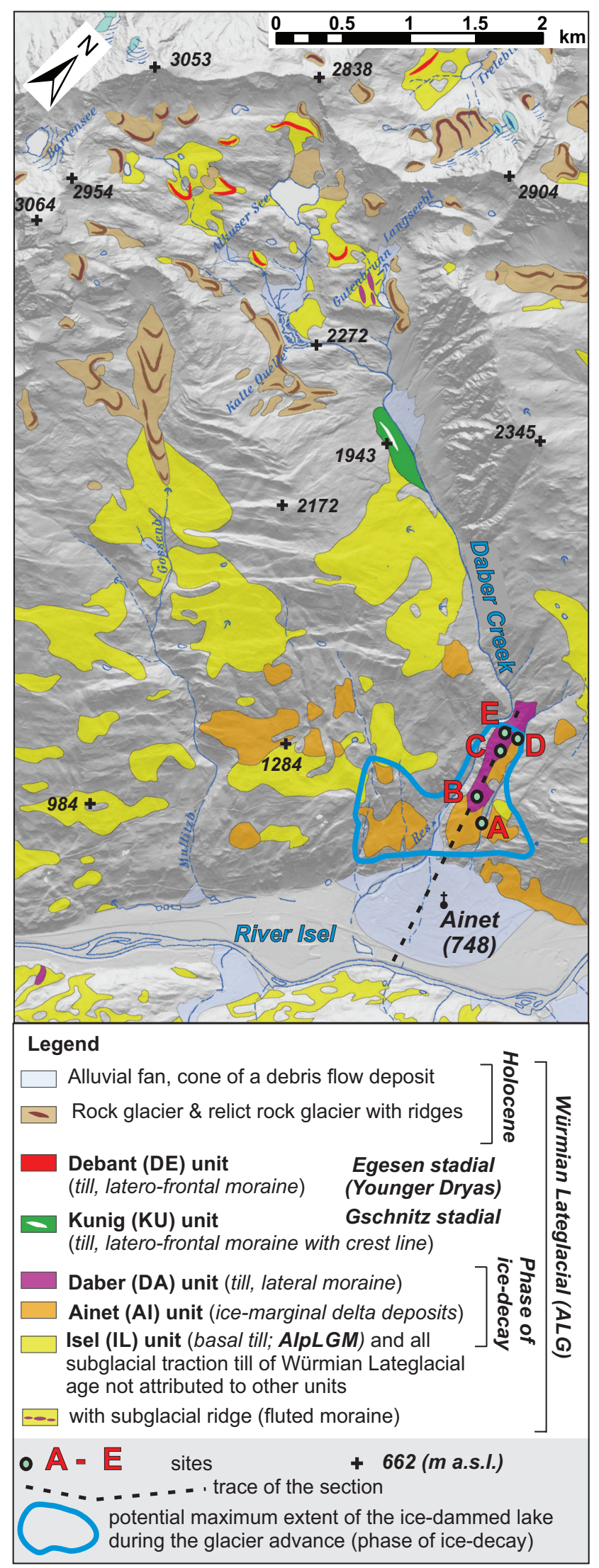

Fig. 2: Simplified map showing the Quaternary sediments of the Daber Valley with important outcrops (A-E) (shaded relief image from TIRIS online map of the province of Tyrol: www.tirol.gv.at). 
known ice direction (using till macrofabrics to indicate main ice direction, Reitner et al., 2010). Samples were taken at $90^{\circ}$ into the cut exposure face parallel to the ice flow direction and therefore the assumed the direction of principle axis of stress. Once the samples were obtained, they were plastic wrapped and transported back to the laboratory for preparation and thin section production (Rice et al., 2014; Menzies and van der Meer, 2017). On curing and hardening, the samples were thin sectioned to approximately $35 \mu \mathrm{m}$ in thickness and placed upon $5 \times 7 \mathrm{~cm}$ glass slides for examination using a low magnification $(<50 \times)$ petrological microscope.

\subsection{Analyses}

There is considerable spatial variability in matrix grain size, and clast type and size in the thin sections. Detailed descriptions of all the thin sections obtained including sediment colour, and microstructures present concerning all the samples are presented in Table 1. On each thin sections all microstructures present were counted. The definitions of the microstructures used in this paper have been used extensively in previous literature: definitions can be found in Menzies and van der Meer (2018, chapter 21). The thin sections shown in Figs. 6, 7, 8, and 9 are the best representative thin sections images available. An exhaustive illustration of all thin section images would be too large for publication.

\section{Results and interpretation regarding genesis and palaeogeography}

\subsection{Field evidence and macroscopical description} Site A (WGS $8446^{\circ} 51.954^{\prime} \mathrm{N}, 12^{\circ} 42.151^{\prime} \mathrm{E}, 945 \mathrm{~m}$ a.s.l) represents the stratigraphically - lowest deposit (Isel unit, Figs. 2, 3). It is a grey, highly consolidated massive and matrix-supported diamicton (lithofacies $\mathrm{Dmm}(\mathrm{s})$ ) with sub-horizontal shear planes (fissility) and rare striated clasts lying unconformably on bedrock (Fig. 4a,

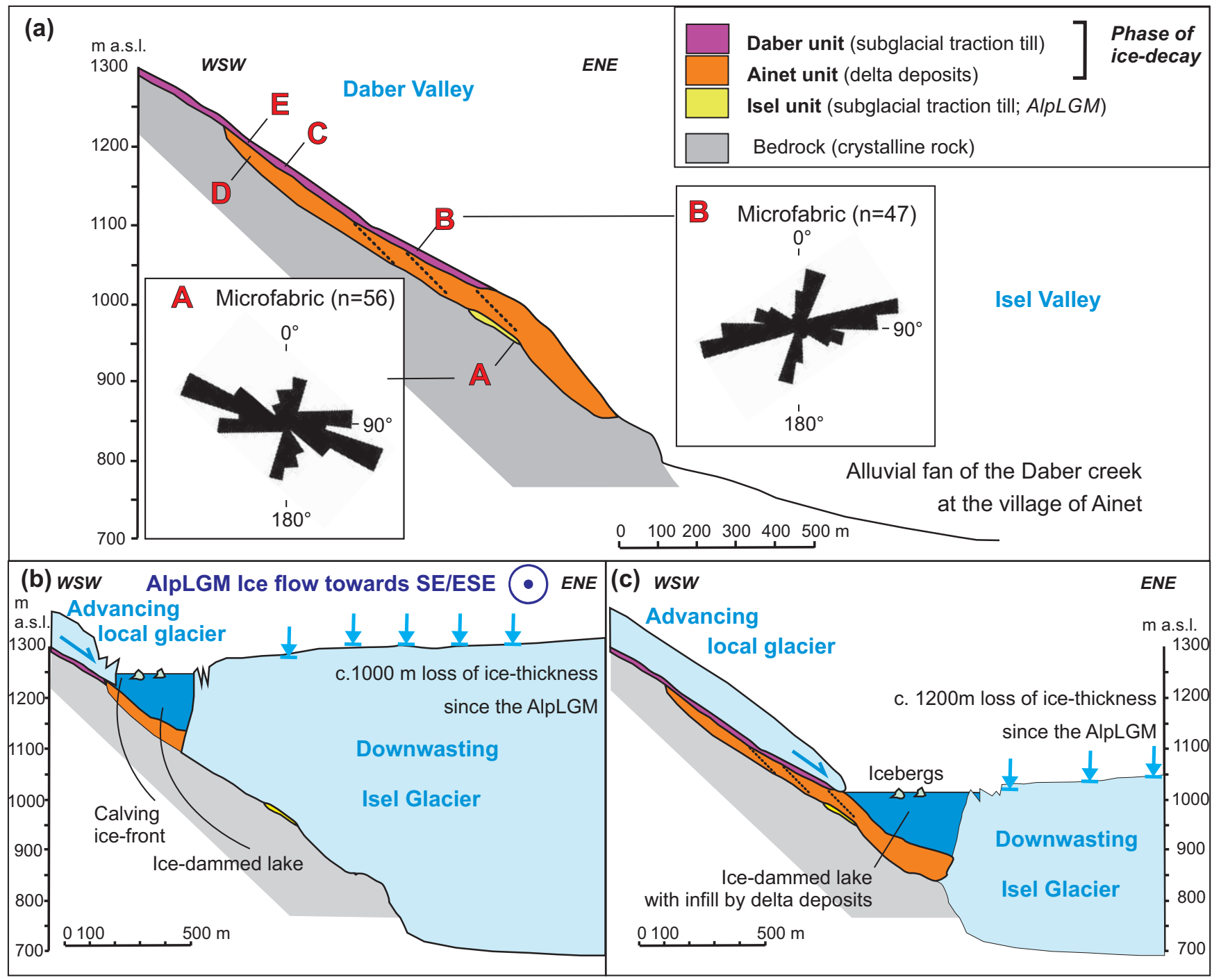

Fig. 3: (a) Section east of the lower Daber Valley with the location of important outcrops A-E and with rose diagrams showing the microclast fabric (orientation of the long axis) in the thin sections at sites A and B when corrected to thin section sampling azimuth. The AlpLGM (Isel unit, site A) till has a mean azimuth of $97^{\circ}$ whereas the Lateglacial till (Daber unit; site B) exhibits one of $66^{\circ}$. (b) and (c) show palaeogeographic scenarios explaining the formation of the Daber unit and the Ainet unit during the Lateglacial phase of ice-decay. In addition, the ice flow direction in the Isel Valley during the AlpLGM towards SE/ESE is indicated. 


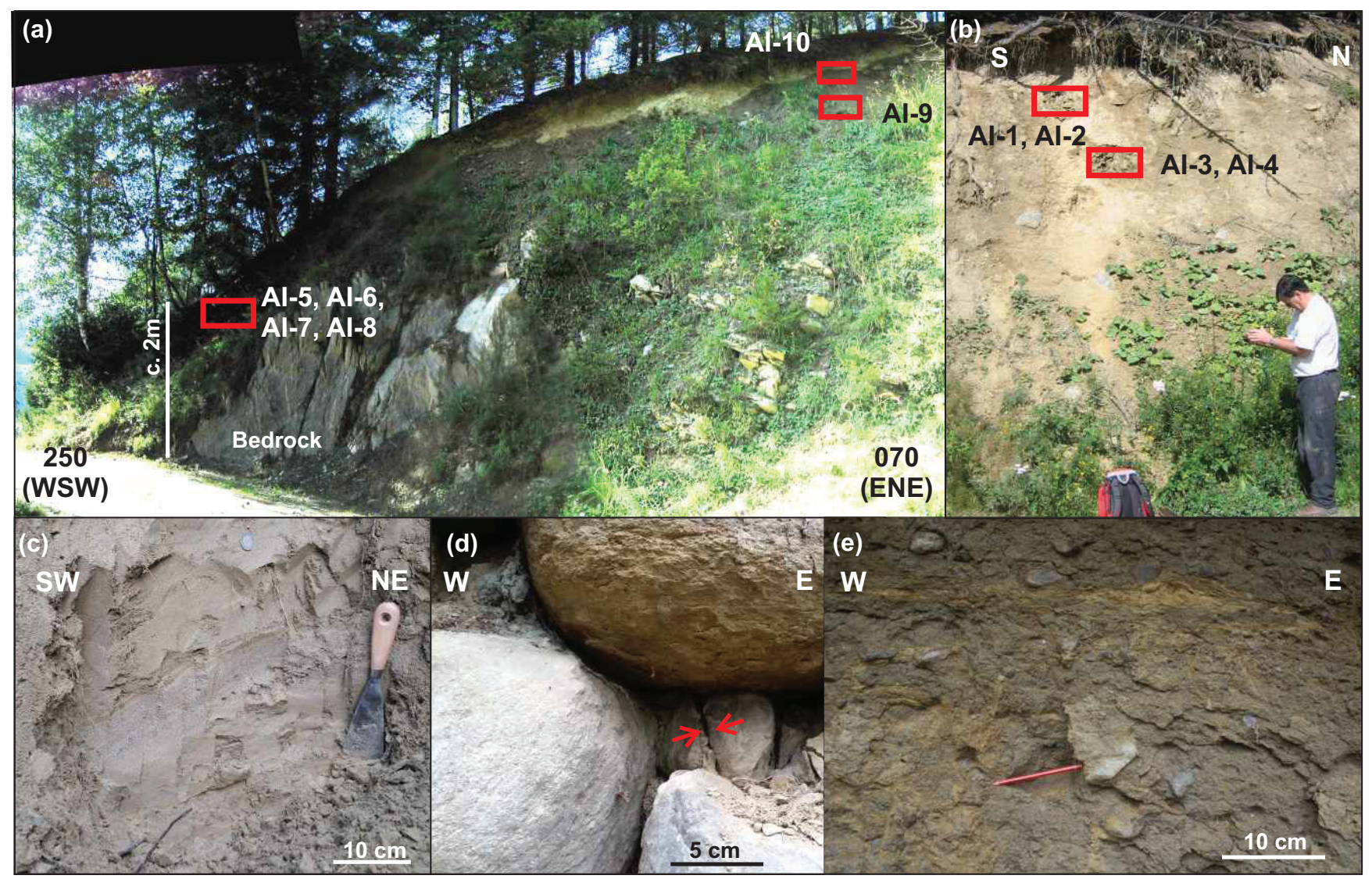

Fig. 4: Outcrop images (a) Site A with the sample sites Al-5 to Al-10 of the Isel unit (subglacial till, AlpLGM) on top of bedrock. Sample site of Al-5 to Al-8 is identical with that of sample 5 (for grain-size; in Fig. 5). (b) Site B with the sample sites Al-1 to Al-4 of the Daber unit (subglacial till, phase of ice-decay). Sample 4 (for grain-size; in Fig. 5) was also taken at this site. (c) Graded to massive sand (sample 1 in Fig. 5) of the Ainet unit (delta deposits) at site D. (d) Cracked pebble (red arrow indicates fracture) within clast supported cobbles with well-rounded clasts (Ainet unit, delta deposits) below site B. (e) Dark-grey subglacial till of the Daber unit with shear planes and with deformed sand layers at site E (modified after Reitner et al., 2016).

and sample 5 in Fig. 5a). The clasts consist of predominantly paragneiss and mica schist but also of eclogite and quartz veins and, thus, lithologies (Fig. 5b) which are present on the northern side of the Isel Valley. Such a provenance is also indicated by the occasional occurrence of the prominent tonalite, which appears to have been quarried from $10 \mathrm{~km}$ up valley. This deposit is interpreted as characteristic of subglacial traction till (mélange) (Menzies, 1990; Hoffmann and Piotrowski, 2001; Evans et al., 2006; Rice et al., 2018; Menzies et al., 2018) deposited by the Isel Glacier. It is unconformably overlain by a sediment package dominated by sandy gravels partly with boulders (Ainet unit). In all outcrops examined, clinoforms made up of planar-bedded sediment with a gentle dip of $10^{\circ}$ to $20^{\circ}$ towards the SW are evident. In the lower part, a transition to sandy and silty layers with isolated glacially shaped clasts, interpreted as dropstones, are present. A typical stratigraphic situation occurs at site $D\left(46^{\circ} 52.102^{\prime} \mathrm{N}, 12^{\circ} 42.676^{\prime} \mathrm{E}, 1190 \mathrm{~m}\right.$.) with clast-supported planar-bedded gravel (Gcp; sample 2) and massive to graded sand ( $\mathrm{Sm}, \mathrm{Sg}$; sample 1; Fig. 4c) with occasional dropstones (Smd) (see Eyles and Miall, 1984; Keller, 1996 for lithofacies code system). The uppermost layers consist of well-rounded cobbles where occasionally cracked pebbles are present (Fig. 4d). In total, this deposit is interpreted as a suite of deltaic sediments. It is overlain by a grey, highly-consolidated, macroscopically massive, matrix-supported diamicton with shear planes (lithofacies Dmm(s); Daber unit) which composes the surface of the ridge from around $1300 \mathrm{~m}$ down to $\sim 1000 \mathrm{~m}$ a.s.l. with outcrops at the site B (Fig. $4 b, 46^{\circ} 52.062^{\prime} \mathrm{N} 12^{\circ} 42.292^{\prime} \mathrm{E}, 1060 \mathrm{~m}$ a.s.l, sample 4) ) and site $C\left(46^{\circ} 52.125^{\prime} \mathrm{N}, 12^{\circ} 42.541^{\prime} \mathrm{E}\right.$, $1170 \mathrm{~m}$ a.s.l., sample 3). Some of the outcrops, as at site $\mathrm{E}\left(46^{\circ} 52.151^{\prime} \mathrm{N}, 12^{\circ} 42.615^{\prime} \mathrm{E}, 1205 \mathrm{~m}\right.$ a.s.l.), show deformed sand-stingers within the diamicton (Fig. 4e). In contrast to the diamictons at site $A$, a visually evident much higher proportion of eclogite / amphibolite is evident in the larger clasts (>32 mm). This deposit is a subglacial traction till originating up-ice from the upper Daber Valley catchment.

The grain size analyses (Fig. 5a) shows that the upper till (Daber unit) is finer grained than the lower till with an $\geq 20 \%$ higher content of fines (clay and silt). However, the grain-size distribution of the tills is within the range of other Alpine tills (Reitner, 2005; Reitner et al., 2010; Menzies and Reitner, 2016, 2019). The clast lithology distribution (Fig. 5b) is for all four samples (tills from sites A, $B, C$ and delta deposit from $D$ ) and is quite uniform with a dominance of paragneiss and mica schist in the grainsize fraction 8-32 $\mathrm{mm}$. The higher eclogite and amphibolite content in the upper till, based on clasts $>32 \mathrm{~mm}$, 


\begin{tabular}{|c|c|c|c|c|c|c|c|c|}
\hline $\begin{array}{l}\text { Ainet Samples } \\
\text { Al }\end{array}$ & Colour & $\begin{array}{l}\text { Munsell } \\
\text { Colour }\end{array}$ & $\begin{array}{l}\text { Domain } \\
(\mathrm{dm})\end{array}$ & $\begin{array}{l}\text { Grain stacks } \\
\text { (gls) }\end{array}$ & $\begin{array}{l}\text { Rotation } \\
\text { (rt) }\end{array}$ & $\begin{array}{l}\text { Edge-to-Edge } \\
\text { grain crushing (E) }\end{array}$ & $\begin{array}{l}\text { Microshear } \\
(\mathrm{ms})\end{array}$ & $\begin{array}{l}\text { Deformation } \\
\text { bands (db) }\end{array}$ \\
\hline \multicolumn{9}{|l|}{$\begin{array}{l}\text { LGM } \\
\text { (Isel unit; site A) }\end{array}$} \\
\hline 8ap & $\mathrm{b} / \mathrm{gb}$ & 7.5YR 5/2 & . & - & - & - & - & - \\
\hline 9ap & $\mathrm{g}$ & 7.5YR 5/ & $\cdot$ & • & $\cdot$ & & $\cdot$ & $\cdot$ \\
\hline $9 \mathrm{cp}$ & g & 7.5YR 5/ & $\cdot$ & $\cdot$ & & & & \\
\hline 9gp & g & 7.5YR 5/ & . & & & & & $\cdot$ \\
\hline 10ap & $\mathrm{dkb} / \mathrm{rb}$ & $\begin{array}{l}7.5 \mathrm{Yr} 3 / 2, \\
5 \mathrm{YR} 6 / 4\end{array}$ & . & • & • & & . & \\
\hline $10 \mathrm{dp}$ & $\mathrm{dkb} / \mathrm{rb}$ & $\begin{array}{l}7.5 Y R 3 / 2, \\
\text { 5YR } 6 / 4\end{array}$ & & • & $\cdot$ & & $\cdot$ & $\cdot$ \\
\hline $10 f p$ & $\mathrm{dkb} / \mathrm{rb}$ & $\begin{array}{l}7.5 Y R 3 / 2, \\
5 Y R 6 / 4\end{array}$ & - & • & • & & - & • \\
\hline $10 \mathrm{np}$ & $\mathrm{dkb} / \mathrm{rb}$ & $\begin{array}{l}7.5 Y r 3 / 2, \\
5 Y R 6 / 4\end{array}$ & & • & • & & . & • \\
\hline \multicolumn{9}{|l|}{$\begin{array}{l}\text { Lateglacial } \\
\text { (Daber unit; site B) }\end{array}$} \\
\hline 3ар & $\mathrm{lb}$ & 7.5YR 6/4 & & $\cdot$ & $\cdot$ & $\cdot$ & & $\cdot$ \\
\hline $3 d p$ & $\mathrm{~b} / \mathrm{lb}$ & 7.5YR 6/6 & . & $\cdot$ & $\cdot$ & & & $\cdot$ \\
\hline 3ер & $\mathrm{g}$ & $5 /$ & $\cdot$ & • & $\cdot$ & - & $\cdot$ & • \\
\hline $3 f p$ & $\mathrm{~b} / \mathrm{rb}$ & 5YR 5/2 & & $\cdot$ & $\cdot$ & & $\cdot$ & $\cdot$ \\
\hline $2 a p$ & $\mathrm{rb}$ & $5 Y R 4 / 2$ & . & • & • & • & . & • \\
\hline $2 c p$ & $\mathrm{rb}$ & $5 Y R 4 / 2$ & . & • & $\cdot$ & & $\cdot$ & $\cdot$ \\
\hline $2 f p$ & $\mathrm{lb} / \mathrm{dkb}$ & $\begin{array}{l}7.5 \mathrm{YR} 3 / 2 \\
7.5 \mathrm{Yr} 6 / 6\end{array}$ & $\cdot$ & - & $\cdot$ & - & $\cdot$ & • \\
\hline $2 \mathrm{kp}$ & $\mathrm{g}$ & 7.5YR 5/ & - & • & $\cdot$ & & $\cdot$ & $\cdot$ \\
\hline
\end{tabular}

Table 1: Summary of microstructures in the Ainet samples. Abbreviations are: Colour column: dkb - dark brown, $g$ - gray, lb - light brown; b/lb brown -light brown; dkb/lb - dark brown - light brown; b/rb - brown- reddish brown; rb - reddish brown; dkb/rd - dark brown , reddish brown; Munsell column: All colours are of the 7.5YR or 5YR Hue with varying Chroma. Microstructures: $r \mathrm{rt}=$ rotation structures; gls = grain stacks; 'E' = edge-to-edge grain fractures, $\mathrm{ms}=$ microshears, and $\mathrm{db}=$ deformation bands. All microstructures are described in van der Meer and Menzies (2011).

is absent from the smaller grain-size classes, most likely due to a higher resistance of these lithologies to glacial comminution compared to "weaker" ones (paragneiss, mica schists). Interestingly, the lower subglacial till (Isel unit) shows similar clast roundness (Fig. 5c) as the overlying delta foreset deposits possibly indicating that the source material of the delta deposits is reworked till from the surrounding valley flanks. The higher content of subangular clasts in the upper till samples is significant but there is no higher portion of subrounded clasts which could be expected due to glacial comminution.

The additional field and laboratory data support the principal interpretation of this sequence by Reitner et al. (2016) as a document of two different glacial advances. The Isel unit made up of a subglacial traction till overlying bedrock is best explained as a deposit of the Isel Glacier (a branch of the Drau Glacier/lce Stream) flowing along the valley axis during the AlpLGM (Figs. 1, 3b). The formation of the Ainet unit consisting of predominantly coarse-grained deltaic sediments took place in a small, ephemeral ice-dammed lake (Fig. 2, with a potential maximum extent) with a varying extent after the Isel Glacier has lost an ice thickness of around $1000 \mathrm{~m}$ following the collapse of the AlpLGM glaciation. Based on the dip of the foreset beds and the limited roundness of the clasts (Fig. 5c), the infill was deposited after a rather short transport distance by a precursor of the Daber creek. The Daber unit, consisting again of a subglacial traction till, documents an advance of the Daber (Valley) Glacier over the delta deposits (Ainet unit) south-westward towards its Lateglacial maximum position (Fig. 3c). Such a setting is characteristic of the early Lateglacial phase of ice-decay, when local glaciers reacted with brief re-advances after separation from the decaying glacier complex by (Reitner, 2007). Cracked pebbles within Ainet unit (Fig. 4d) support this scenario, indicating additional loading typical for glacially overridden clast-supported deposits (e.g. van Husen, 1977). The sand deformed layers, typically roughly linear in form but sheared parallel to the main ice direction (south-westward), within the till at site E (Fig. 4e) were interpreted by Reitner et al. (2016) as a result of ice-bed-decoupling, most probably due to a high groundwater table during the advance into the lake with the deformation structures as an evidence of deformable bed conditions. The presence of deformation 


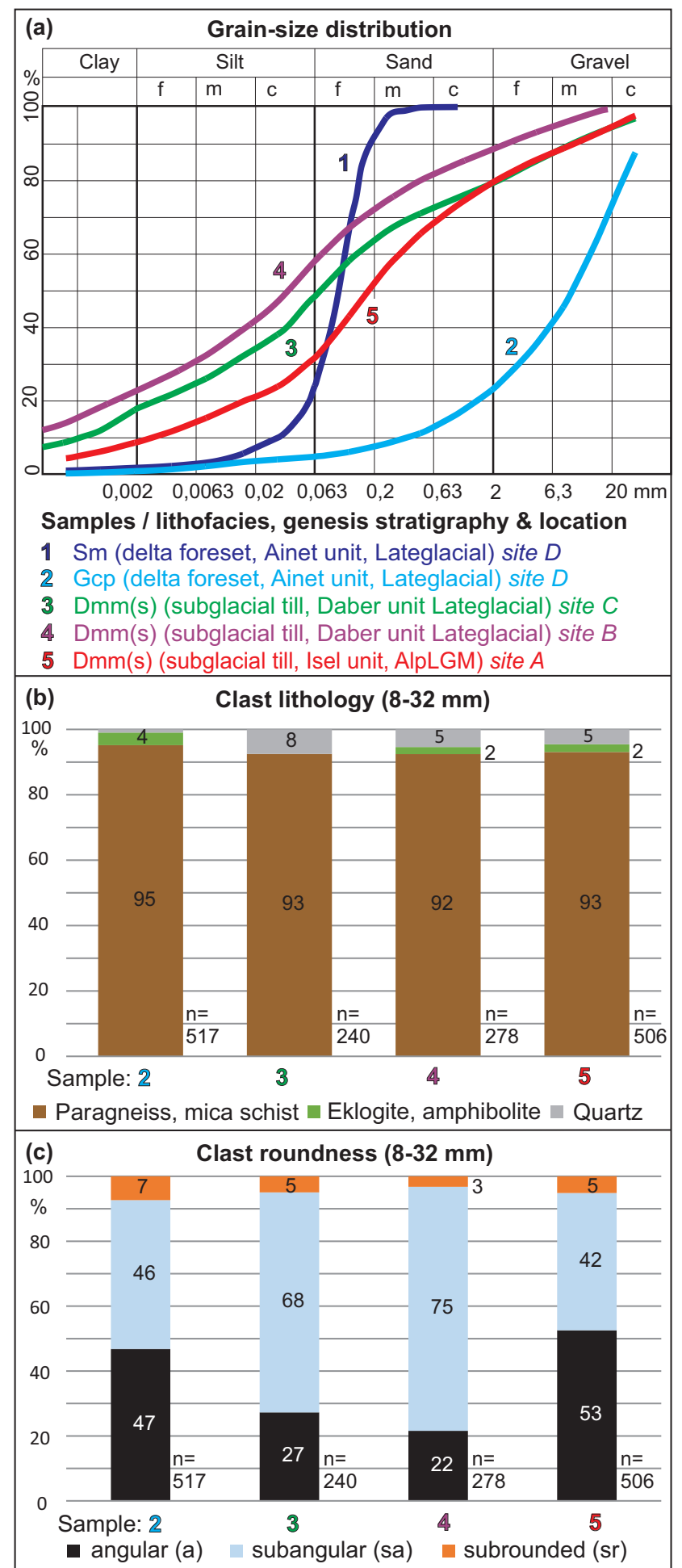

Fig. 5: (a) Grain size-distribution, (b) clast lithology and (c) roundness of different subglacial tills and delta deposits from sites A-D (for location see Figs 2, 3). Grain-size: $f$ - fine; $m$ - medium; c - coarse. Lithofacies: Sm - Sand, massive; Gcp - Gravel, clast-supported, planar-bedded; Dmm(s) - Diamicton, matrix-supported, massive with shear-planes.

structures (deformed sand layers, shear planes) and the additional evidence from micro-sedimentology of these tills, discussed below, suggest there is clear evidence that these subglacial sediments were formed in warm wet-based subglacial conditions.

\subsection{Micromorphological descriptions}

\subsubsection{Isel unit samples (Alpine LGM; site A, in Figs. 2,} 3a, 4a)

Sample Al-8 is a single representative sample of a matrix-supported, massive diamicton taken from location A. The description of the micromorphology is based on one subsample (Al-8ap; Table 1). Subsample Al-8ap contains a large subrounded clast and two clay-rich lee-side shadow deposits of clay (green) (Fig. 6a). This thin section carries a strong shear sense direction to the upper right of the sample which might be interpreted as a shear sense of around $33^{\circ} \mathrm{NE}$ in relation to the sample azimuth of $48^{\circ}$ NE. A rotation structure to the right of this clast (with a clockwise sense of rotation) and several lineations and grain stacks occur. Extensive edge-to-edge grain crushing events (E) can be noted (Menzies et al., 2013). Two deformation bands occur at the upper right of the large clast at approximately $90^{\circ}$ to each other (indicative of a strongly different shear sense direction beyond the edge of the large clast) which may have strongly influenced the deformation partitioning in this part of the sediment (Fossen et al., 2017, 2019). The thin section was taken at $48^{\circ} \mathrm{NE}$ parallel to the exposure face.

Sample Al-9 was taken 3-4 $\mathrm{m}$ to the right and above Al-8 (Fig. 4a). The micro-morphological description is based on three subsamples (Al-9ap, Al-9cp, Al-9gp; Table 1). The thin section was taken at $47^{\circ} \mathrm{NE}$ parallel to the exposure face and carries the same sense of shear oblique to the sampling orientation as did Sample Al-8. Subsample AI9ap contains a large zone of crudely banded clays (green) (Fig. 6b) that has been offset by a moderately (left) dipping extensional (normal) fault that can also be observed in Al-9cp. To the right of the fault plane can be seen several sub-parallel deformation bands (orange) and an elongated rotation structure. To the left of the crack/fissure a microshear and a deformation band appear to be oriented almost at $90^{\circ}$ to the other deformation bands and lineations in the sample. Subsample Al-9cp is like Al9ap with a similar fault plane (Fig. $6 c$ ). This thin section contains a large area of intruded clay (green) along the fault plane that appears to have been spread from the leftward direct into the diamicton at this site. Subsample Al-9gp contains a large massive clay (green) intruded into a relatively coarse diamictic unit (Fig. $6 \mathrm{~d}$ ). Along fissure (possibly the result of localized faulting as seen the previous two images) and void edges even finer clay appears to have been deposited (dark green) (Fossen et al., 2019). Several sub-parallel deformation bands (orange) occur within the coarser diamicton.

Sample Al-10: The location of sample Al-10 occurs less than a metre above Al-9 (Fig. 4a). The thin section was taken at $46^{\circ} \mathrm{NE}$ parallel to the exposure face. The micro-morphological description is based on four subsamples (Al-10ap, Al-10dp, Al-10fp, Al-10np; Table 1). Subsample Al-10ap is a typical diamicton that has been strongly deformed in multiple directions as seen by the cross-cutting lineations and 


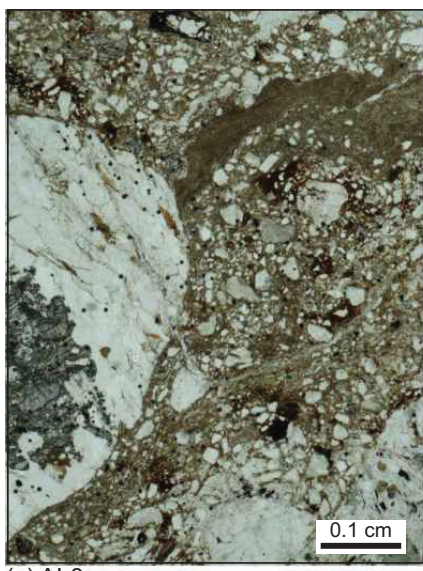

(a) Al-8ap

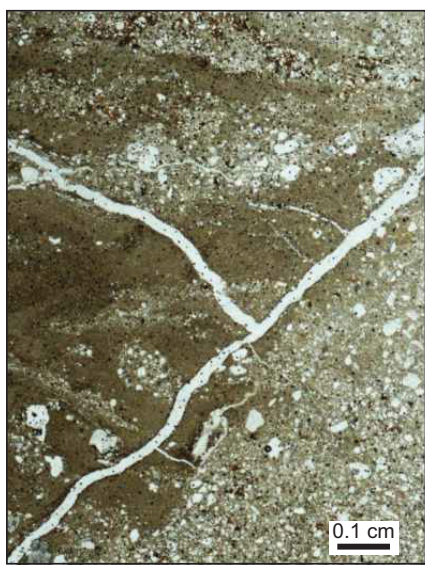

(c) Al-9cp
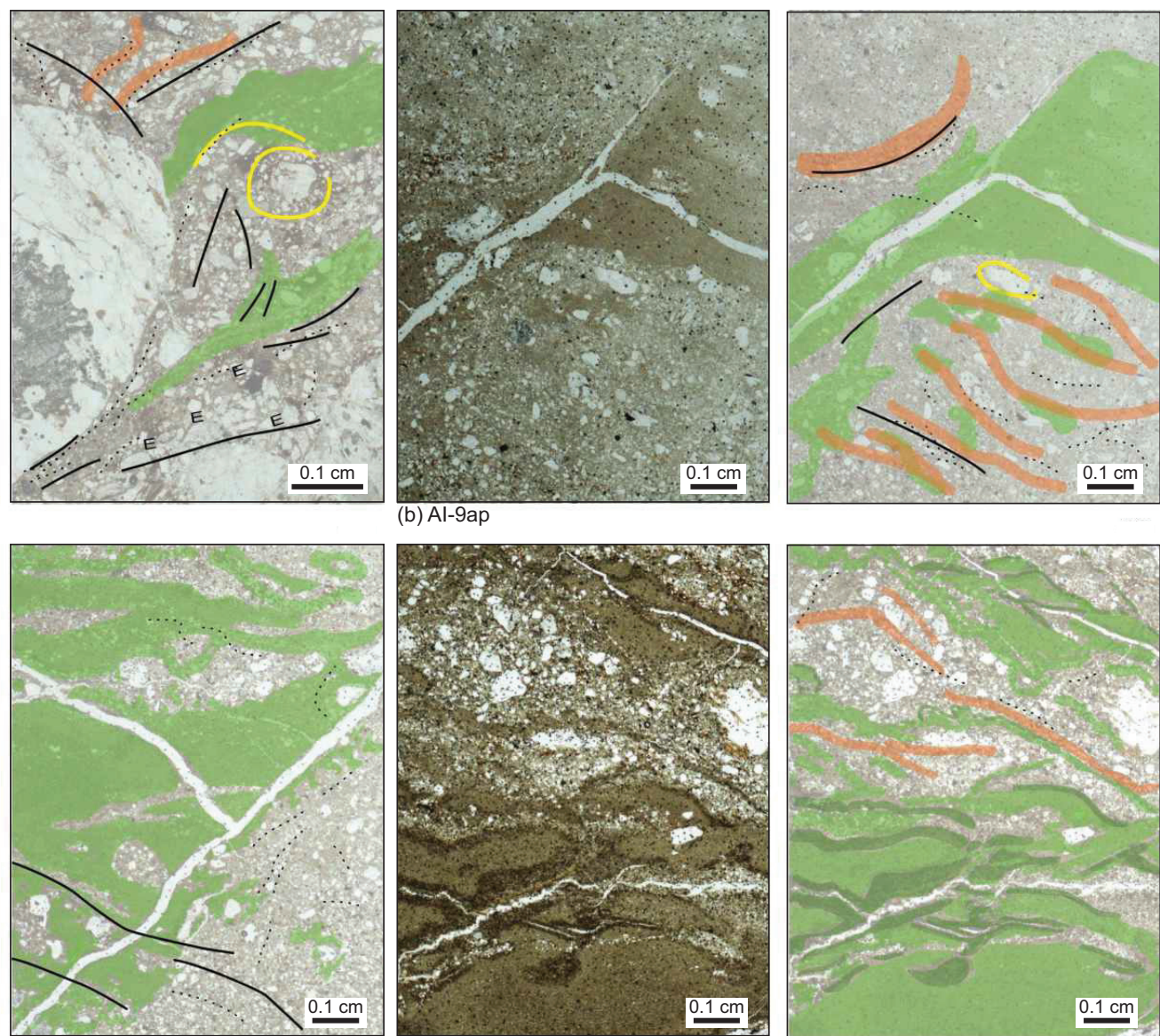

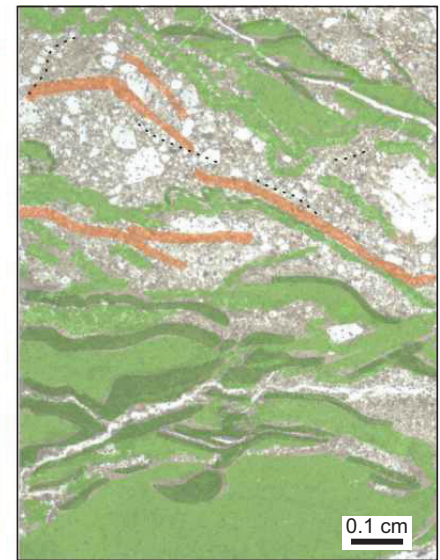

$0.1 \mathrm{~cm}$

Fig. 6: Photomicrographs of thin sections (Al-8ap, 9ap, cp, gp) from sample sites A in LGM sediments (Fig. 3a). Note all the images are in plane light and have an annotated duplicate. In sample Al-8ap note higher clay content domains in green, and evidence of edge-to-edge grain crushing events marked as " $\mathrm{E}^{\prime}$. In samples Al-9ap, 9cp and 9gp note higher clay domains in green. In sample Al-9gp zones of very high clay content (darker green) along the edges of the high clay content can be observed. Note microshears are solid blacklines, grain stacks are black dotted lines, rotation structures are thin yellow lines, deformation bands are in orange. Note scale $(1 \mathrm{~mm})$ on each image and top of each thin section is at the top of the image.

grain stacks (Fig. 7a). A large domain with a slightly higher clay content occurs in this image that seems to be chronologically older than most of the other microstructures. The domain appears to have been overprinted by other microstructures thus the chrono-sequence suggested. Subsample Al-10dp is a reddish brown diamicton with several large diffuse particle-oriented zones that define deformation bands bending around larger subrounded clasts that also show surrounding rotation structures (Fig. 7b). Subsample Al-10fp is a heavily deformed diamicton with many rotation structures, as well as microshears and deformation bands (orange) (Fig. 7c). A large, diffuse, clay-rich domain occur in this thin section. The large clast in the lower centre of the image illustrates well the effect of deforming rotation of smaller particles (van der Meer, 1993, 1996, 1997; Hiemstra and van der Meer, 1997; Phillips, 2006). This thin section exhibits many closely spaced rotation structures illustrative of the strong, possibly, repeated local deformation this diamicton as undergone. It seems likely that the rotation structures are of multiple generations (Schoneveld, 1977; Simpson and De Paor, 1993; Passchier and Trouw, 2005; Phillips, 2006; Fossen et al., 2017, 2019). Subsample Al-10np is like the other Al-10 subsamples in that it carries all the typical microstructures seen in the other samples (Fig. 7d).

\subsubsection{Daber unit samples (Lateglacial phase of ice decay; site $B$ in Figs. 2, 3a, 4b)}

Sample Al-3 is the stratigraphically lowest sample from location $B$. The various characteristics of this single representative sample are described here based on four subsamples (Al-3ap, Al-3dp, Al-3ep, Al-3fp; Table 1). Sample $\mathrm{Al}-3$ is a fine grained diamicton with a high concentration of small subangular to subrounded clasts. Macro-sedimentology reveals a strong clast fabric, with an exotic clast provenance, and subangular and subrounded clasts within a fine-grained matrix. This distinct sedimentology in conjunction with the overall micro-sedimentological evidence (for a glossary of terms see: Menzies, 2000, 2012; Rice et al., 2014; Menzies and van der Meer, 2018), suggests this diamicton is a subglacial till (Fig.5a; sample 4) (Phillips et al., 2018; Büchi et al., 2017; Evans, 2017; Menzies and van der Meer, 2018). Thin section samples were taken at an orientation of $44^{\circ} \mathrm{NE}$, parallel to the exposure face. The thin sections shown in Figure 6 were randomly chosen as illustrative of micro-sedimentological conditions in this diamicton.

Subsample Al-3ap (Fig. 8a) shows rotation structures (in yellow) (where no true sense of rotation direction can be established), grain stacks (black dashed lines) and a series 


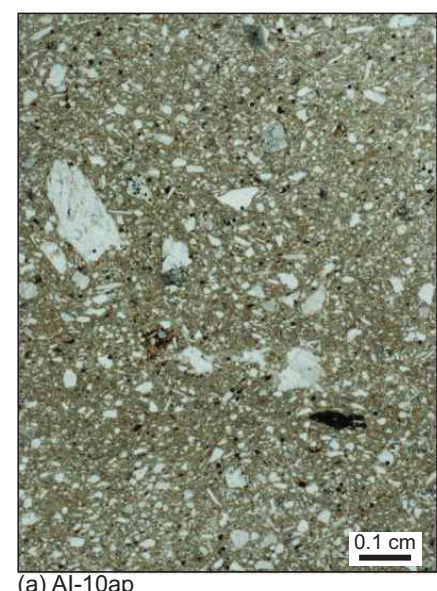

a) Al-10ap

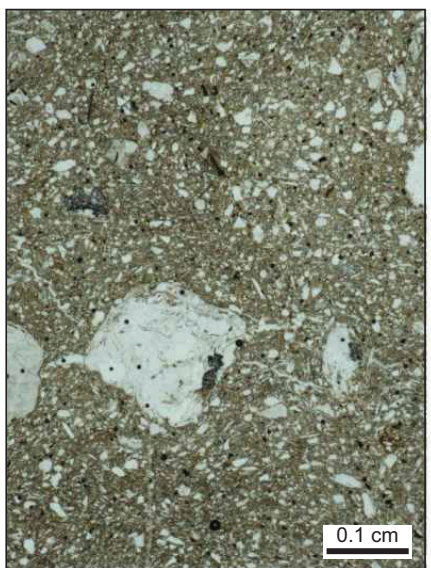

(c) Al-10fp
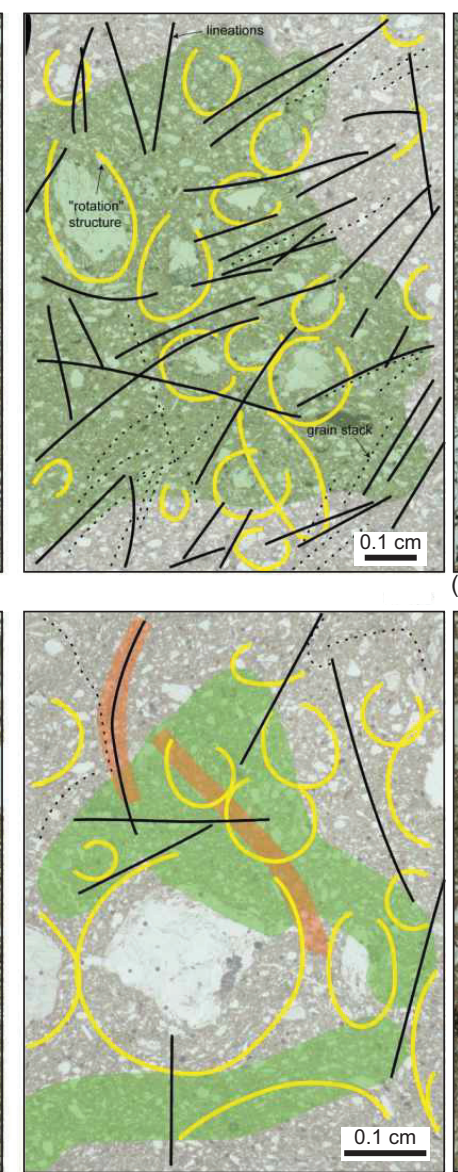

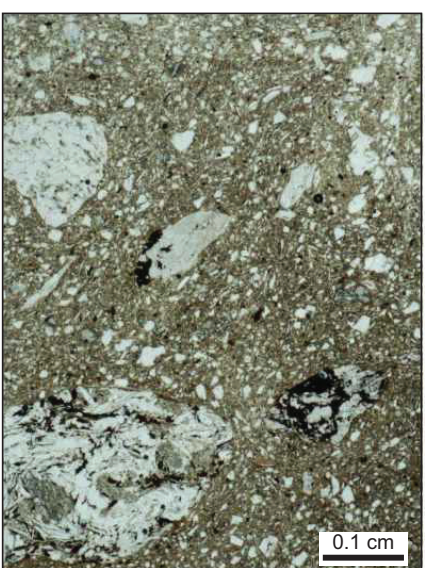

(b) Al-10dp

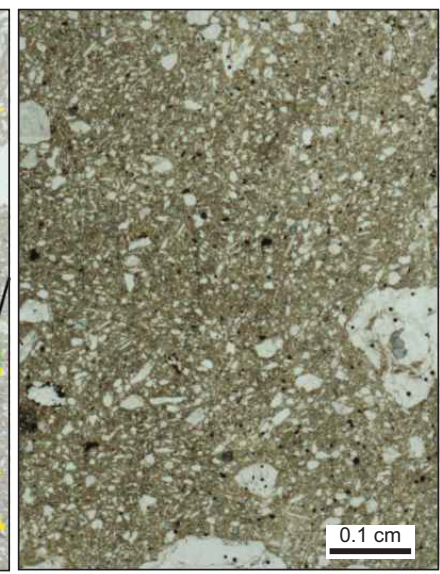

(d) Al-10np
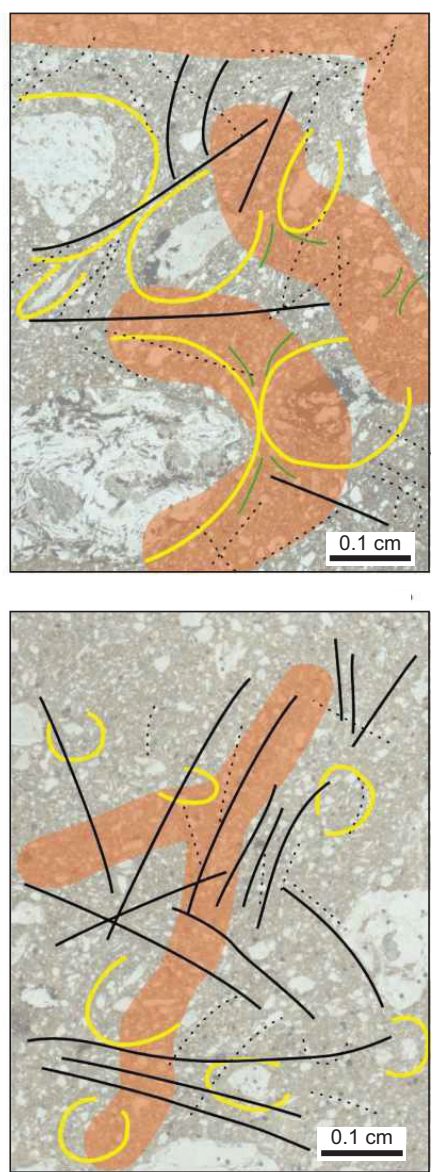

Fig.7: Photomicrographs of thin sections (Al-10ap, dp, fp, np) from sample site A in LGM sediments (Fig. 3a). Note all the images are in plane light and have an annotated duplicate. In samples Al-10ap and 10fp note large clay-rich clay domains in green. In sample Al-10dp note necking structures as thin green lines. Note microshears are solid black lines, grain stacks are black dotted lines, rotation structures are thin yellow lines, deformation bands are in orange. Note scale $(1 \mathrm{~mm})$ on each image and top of each thin section is at the top of the image.

of deformation bands (orange). Deformation bands are differentiated based on the alignment of elongate sand grains and the presence of a locally oriented micro-plasmic fabric. A strong preferred orientation of the bands to shear direction occurs obliquely from bottom right to upper left. Subsample Al-3dp exhibits a strong preferred orientation with numerous near parallel deformation bands (orange) clearly showing an oblique upper left orientation (possibly indicative of a sinistral sense of shear), as in Al-3ap (Fig. 8b). Several rotation structures and grain stacks can be seen. A large 'comet' structure (green) can be seen in the centre from upper centre left to lower centre right that designates some partitioning of deformation around this structure. This 'partitioning' might indicate a shear shadow (an area of lower strain) in the lea of the comet structure indicating an oblique shear sense from left to right parallel to ice shear direction. Subsample Al-3ep contains similar deformation bands (orange) as the previous samples (Fig. 8c). Two larger subrounded clasts appear to split the thin section microstructures into two groups with many deformation bands in the upper right quadrant oriented like those in subsamples Al 3ap and 3dp (Fig. 8b). It seems likely the clasts acted as localized strain partitioning elements in the general deformation of the matrix. Grain stacks in the lower quadrant cross-cut each other and a group of near parallel microshears occur below the large clast to the left of the image. Subsample Al-3fp with a reddish-brown matrix contains several large subrounded clasts (Fig. 8d). Several large rotation structures can be observed as well as deformation bands (orange), the latter possibly post-date the rotation structures. The effect of the large clasts and rotation structures would appear to indicate a chrono-sequence of deformation partitioning that may illustrate changing rheological conditions possibly a reduced localized pore water content (Menzies et al., 2016). Grain stacks appear to exhibit no orientation although a large number near-parallel the deformation bands. Sample Al-2 is located less than a metre above Al-3 and will be described based on four subsamples (Al-2ap, Al-2cp, Al-2fp, Al-2kp; Table 1). Subample Al-2ap has a reddish-brown matrix (Fig. 9a). Distinctive multiple deformation bands and near-parallel grain stacks (black dashed lines) cross this sample (orange) as well as several small rotation structures (yellow). This thin section sample was taken at $46^{\circ} \mathrm{NE}$ parallel to the exposure face. Subsample Al-2cp is reddish-brown matrix diamicton dominated by a large subrounded clasts around which clusters a series of rotation structures and deformation bands (Fig. 9b). The deformation bands have possibly been formed from multiple generations of differing shear 


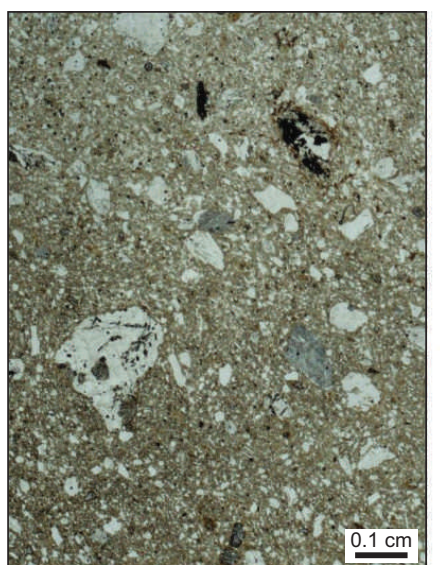

(a) Al-3ap

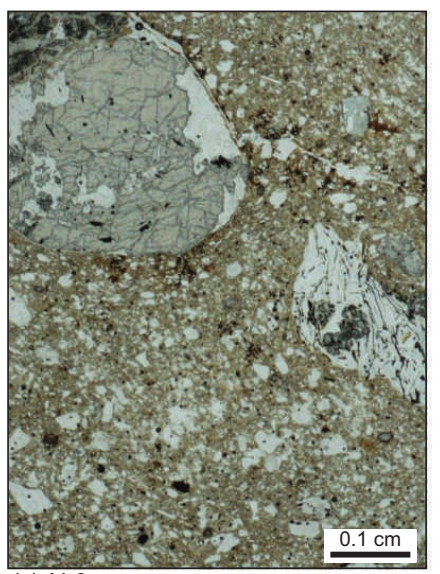

(c) Al-3ep
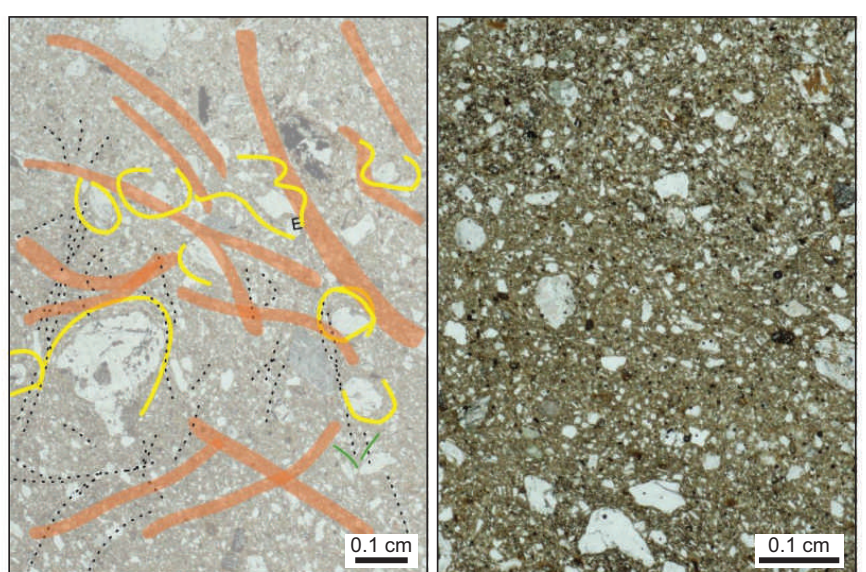

(b) Al-3dp

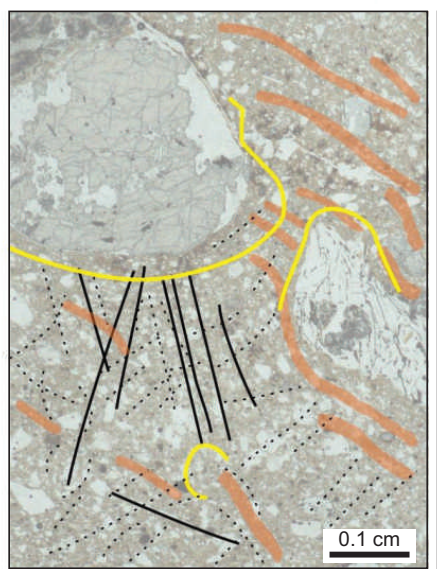

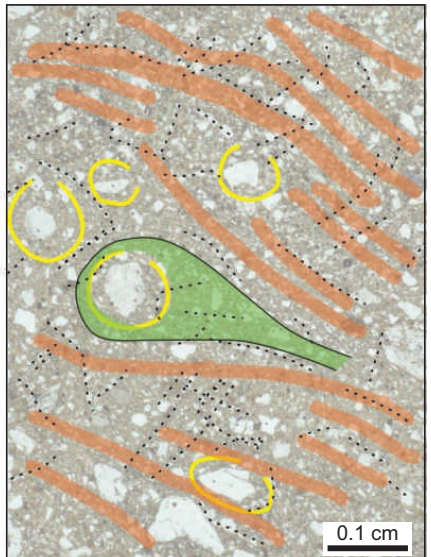

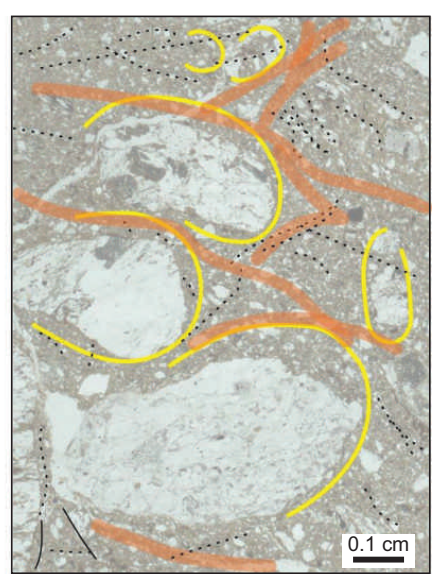

Fig. 8: Photomicrographs of thin sections (Al-3ap, dp, ep, fp) from sample site B in Lateglacial sediments (Fig. 3b). Note all the images are in plane light and have an annotated duplicate. In subsample Al-3dp a comet structure is outlined in green. Note microshears are solid blacklines, grain stacks are black dotted lines, rotation structures are thin yellow lines, deformation bands are in orange, the symbol "E" indicates edge-to-edge crushing, and small green lines are necking structures. Note scale $(1 \mathrm{~mm})$ on each image and top of each thin section is at the top of the image.

direction application. Grain stacks exhibit no apparent orientation and several patches of near parallel microshears can be noted. Subsample Al-2fp contains a large argillan (light brown) bordering the large fracture in the centre of the image (Fig. 9c). A smaller argillan can be noted in the lower right corner of the image. The image is, however, dominated by the large 'till pebble' (in green) that is in the centre of the image. Several grain stacks and deformation bands cross the till pebble that suggests they were emplaced post-till pebble emplacement. Subsample Al-2kp exhibits considerable evidence of deformation in the form of many clay-rich domains and related grain stacks and rotation structures (Fig. 9d). There is the appearance of a lattisepic plasma fabric in cross-polarized light. There is also an indication of an oblique lower right to upper left orientation for many of the linear microstructures.

\section{Discussion}

\subsection{Discussion of the micro-morphology}

In all the above samples, distinct microstructures indicative of various levels of brittle and ductile multi-generational deformation occur. It is evident that these subglacial tills were formed in a temperate wet based environment likely under soft sediment deforming traction conditions (Piotrowski et al., 2004; Lee and Phillips, 2008; Phillips et al., 2011; Vaughan-Hirsch et al., 2013; Büchi et al., 2017). In many instances differing domains attest to scavenging subglacial activity, the rotation of the matrix due to multiple localized shear directions, micro-shearing, and, in many places, zonal deformation (deformational partitioning) in the form of the development of deformation bands. Grain stacks, and in places, edge-to-edge grain crushing events, and between large clasts evidence of necking occurred all indicative of relatively intense soft sediment deformation (Menzies and van der Meer, 2018). There appears to be little difference between the tills of LGM and Lateglacial age other than a difference in microclast fabrics (Table 1 and Fig. 3a). These microfabrics of clasts (orientation of long-axis of clasts) are likely indicative of altered ice flow directions across the eastern slope of the Isel Valley, as might be expected (Evenson, 1971; Carr and Rose, 2003). The microclast fabric for the Lateglacial till (Daber unit, site B) exhibits mean azimuth, when corrected to thin section sampling azimuth, representing an orientation of $66^{\circ}$ and the AlpLGM (Isel unit, site A) till has an azimuth, when corrected to thin section sampling azimuth, indicating an orientation of $97^{\circ}$ (rose 

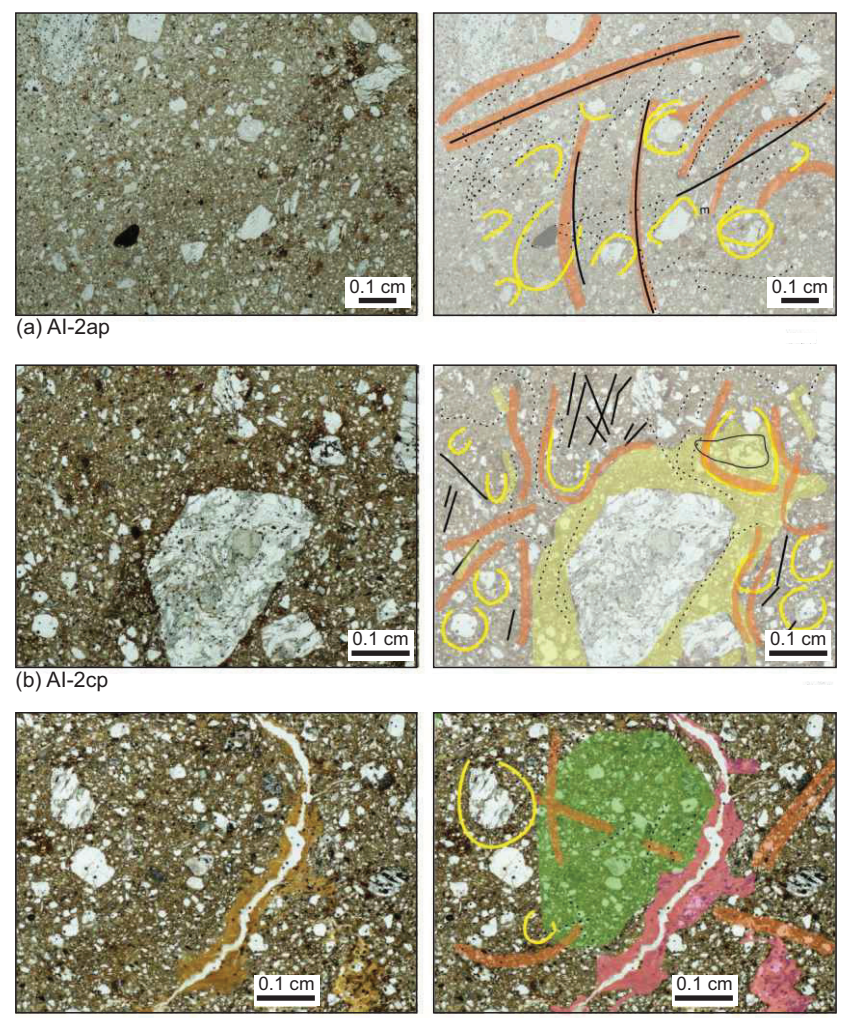

(c) Al-2fp
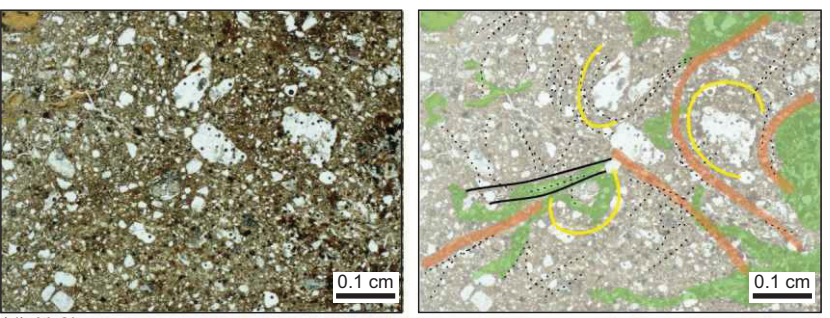

(d) Al-2kp

Fig. 9: Photomicrographs of thin sections (Al-2ap, $c p, f p, k p$ ) from sample site $B$ in Lateglacial sediments (Fig. 3b). Note all the images are in plane light and have an annotated duplicate. In sample Al-2cp a light-yellow halo is shown around a large clast indicative of a higher clay content and domain change. In sample Al-2fp a green shade indicates a till 'clot' or 'pebble' showing a higher clay content and domain change. Also clay argillans, following pore voids, are shown in pink. In sample Al-2kp light green shows presence of higher clay content in the sediments. Note microshears are solid blacklines, grain stacks are black dotted lines, rotation structures are thin yellow lines and, deformation bands are in orange. Note scale $(1 \mathrm{~mm})$ on each image and top of each thin section is at the top of the image.

diagrams in Fig. 3a). It is likely that the younger tills are sourced from the older tills with some reduction in clast sizes and crushing of the matrix following this second phase of deposition (Evans, 2017). Both younger and older tills, likewise, exhibit similar suites of microstructures (Table 1). However, this may be remarkable as the younger till (Daber unit) was formed during a brief time period by a comparably small tributary glacier. Reworking of Lateglacial lake deposits during the advance might have resulted in a more fine-grained matrix in the Lateglacial till (see grain size distribution in Fig. 5a) (Menzies and Reitner, 2016, 2019). The explanation for their likeness must be that once yield strength is overcome in the soft deforming sediment layer a comparable set of microstructures is formed (Menzies et al., 2016).

In specific terms, the thin sections can be variously interpreted by way of differing deformation events or phases. For example: (1) in Al-3ep (Fig. 8c) the slight deviation of short distance lineations (microshears) and grain stacks below the large clast in the upper left side of the image may be explained by the clast acting as a shadow within the stress field of subglacial deformation. (2) The orientation in Al-2ap (Fig. 9a) of the deformation bands might indicate reworking and re-orientation under subglacial ductile stress conditions. (3) The sediment unit in Al-9ap (Fig. 6b) appear to have been deformed in two dominant directions the upper direction conforms to some extent with the ground slope and edge of the valley wall which may be the result of subglacial deformation processes as the ice mass moved across the valley side. (4) It seems likely in Al-10fp (Fig. 7c) many of the rotation structures are probably interrelated as noted above.

\subsection{Discussion of the subglacial conditions}

The tills examined along the eastern slopes of the Isel Valley near Ainet show clear evidence of a subglacial soft sediment deformation signature (Cowan et al., 2012; Phillips et al., 2018). The subglacial sediments in the Isel Valley of differing ages and emplaced under likely differing ice thicknesses show a remarkable similarity. That they should be similar in micro- and macro-sedimentology is not so peculiar as they have both been formed within a soft sediment deforming layer where, once the sediment is stressed beyond its yield strength, similar patterns of microstructures and be expected to develop. As in other locations sediment beneath an ice mass exhibits this form of transport and emplacement mechanism. Once a critical shear stress is reached locally and acts upon the saturated underlying unfrozen sediment, sediment motion can take place (Walter et al., 2014; Phillips et al., 2018; Narloch et al., 2020). Within the sediment, shear zones are likely to form and, at least temporally, effective shear within microscale shear bands (deformation bands) decreases leading to mobilization (Schultz and Siddharthan, 2005; Ballas et al., 2015; Fossen et al., 2017; Brandes et al., 2018; Philit et al., 2018; Carey et al., 2019; Menzies and Reitner, 2019). The mobilization leads to deformation structures forming and evolving as the sediment may temporarily immobilize due to loss of porewater pressure or reduction in shear stress levels as the sediment episodically moves across its bed or ephemeral freezing conditions (Walter et al., 2014; Christianson et al., 2016; Menzies and Reitner, 2016; Menzies et al., 2016; Spagnolo et al., 2016; Phillips et al., 2018; Swift et al., 2018). The 'stick-slip' mobilization / immobilization is likely seen in the variations of types of microstructures formed in the change of rheological phases from brittle to ductile and vice versa at different times and places within the sediment. The evolution of microstructures alluded to by Menzies et al. (2016) appear to indicate evolutionary sequence related to pore water content stress levels and as 
consequence levels of deformation maturity. This evolutionary sequence is seen to occur in many tills as well as those at Ainet. This rheological partitioning of subglacial sediment into mobile and immobile zones is observed in these tills in the Isel Valley (Menzies and Reitner, 2016, 2019). The effect of this 'stick-slip' process is to develop polyphase deformation conditions as evidenced in these samples from the Isel Valley (Hart et al., 2019).

\section{Conclusions}

Investigations of the micro-sedimentology of tills in the Isel Valley illustrate that these subglacial tills were deposited under temperate soft sediment deforming traction bed conditions. With the additional utilization of micro-sedimentological analyses, an improved understanding of subglacial ice dynamics can be achieved leading to the development of new subglacial soft sediment models (Menzies et al., 2016). It seems likely with a high subglacial sediment flux that subglacial tills, investigated here, were emplaced along the valley sides under mobile, temperate basal ice conditions. The tills are of differing ages, but no readily visible difference could be detected between the tills as is expected, being formed from over-yield stress levels. It is likely that the younger till was derived from the older till unit with a slight decrease in overall grain size and possibly a finer matrix as a result of subglacial transport. Both tills carry almost identical suits of microstructures illustrative of having undergone the same mechanisms of transport and emplacement.

It is clear, at least, in the Drau Valley catchment in central southern Austria that subglacial conditions at the height of the last glaciation and later at the demise of the EAIC exhibited conditions not unlike those today underlying modern West Antarctic ice streams. The micro-sedimentological evidence supports the contention that in this ice stream wet temperate soft-bedded deforming conditions prevailed, both during the LGM and Lateglacial phase of the EAIC. This research strongly supports previous work done in northern Austria where comparable findings occurred within the subglacial tills of the Inn Ice Stream's bed (Menzies and Reitner, 2016, 2019). Future research along the Drau valley and other locations in Austria are planned where fast ice streams occurred using micro-sedimentological techniques that can illustrate geological conditions in a way unlike in the past. Knowledge of the subglacial environments using micro-sedimentological techniques illuminates controls in basal ice activity in terms of overall ice sheet mass balance based upon a grasp of basal thermal regimes, sediment availability and rheology, as well as subglacial hydrological conditions.

\section{Acknowledgements}

The authors wishes to thank Marty Ouellette for thin section production and Mike Lozon for his superb draftsmanship. JMR thanks Ljiljana Barbir and Julia Rabeder for preparing the grain-size data. JMz is most grateful to the Geological Survey of Austria and the Commission for Quaternary Research of the Austrian Academy of Science for supporting field work. The authors wish to extend thanks to Emrys Phillips and two anonymous reviewers for their very useful and insightful comments on an earlier version of this paper, which helped much to refine the ideas presented herein.

\section{References}

Andreassen, K., Winsborrow, M., 2009. Signature of ice streaming in Bjørnøyrenna, Polar North Atlantic, through the Pleistocene and implications for icestream dynamics. Annals of Glaciology 50, 17-26. http:// doi:10.3189/172756409789624238

Ballas, G., Fossen, H., Soliva, R., 2015. Factors controlling permeability of cataclastic deformation bands and faults in porous sandstone reservoirs. Journal of Structural Geology 76,1-21. http://dx.doi.org/10.1016/j. jsg.2015.03.013

Brandes, C., Igel, J., Loewer, M., Tanner, D.C., Lang, J., Müller, K., Winsemann, J., 2018. Visualisation and analysis of shear-deformation bands in unconsolidated Pleistocene sand using ground-penetrating radar: Implications for paleoseismological studies. Sedimentary Geology 367, 135-145. https://doi.org/10.1016/j.sedgeo.2018.02.005

Brisbourne, A.M., Smith, A.M., Vaughan, D.G., King, E.C., Davies, D., Bingham, R.G., Smith, E.C., Nias, I.J., Rosier, S.H.R., 2017. Bed conditions of Pine Island Glacier, West Antarctica. Journal of Geophysical Research: Earth Surface 122, 419-433. https://doi:10.1002/2016JF004033

Büchi, M.W., Frank, S.M., Graf, H.R., Menzies, J., Anselmetti, F.S., 2017. Subglacial emplacement of tills and meltwater deposits at the base of overdeepened bedrock troughs. Sedimentology 64, 658-685. https://doi. org/10.1111/sed.12319

Büchi, M.W., Graf, H.R., Haldimann, P., Lowick, S.E., Anselmetti, F.S., 2018. Multiple Quaternary erosion and infill cycles in overdeepened basins of the northern Alpine foreland. Swiss Journal of Geosciences 111, 133-167. https://doi.org/10.1007/s00015-017-02899(0123456789().,-volV)(0123456789(),.-volV)

Burschil, T., Tanner, D.C., Reitner, J.M., Buness, H., Gabriel, G., 2019. Unravelling the shape and stratigraphy of a glacially-overdeepened valley with reflection seismic: the Lienz Basin (Austria) Swiss Journal of Geoscience 112, 341-355. https://doi.org/10.1007/s00015-019-00339-0 Carey, J.M., Crutchley, G.J., Mountjoy, J.J., Petley, D.N., McSaveney, M.J., Lyndsell, B., 2019. Slow episodic movement driven by elevated pore-fluid pressures in shallow subaqueous slopes. Geomorphology 329, 99-107. https://doi.org/10.1016/j.geomorph.2018.12.034

Carr, S.J., Rose, J., 2003. Till fabric patterns and significance: particle response to subglacial stress. Quaternary Science Reviews, 22, 1415-1426. https://doi.org/10.1016/ S0277-3791(03)00125-2

Christianson, K., Jacobel, R.W., Horgan, H.J., Alley, R.B., Anandakrishnan, S., Holland, D.M., DallaSanta, K.J., 2016. Basal conditions at the grounding zone of Whillans Ice Stream, West Antarctica, from ice-penetrating radar. 
Journal of Geophysical Research: Earth Surface, 121, 1954-1983. https://doi.org/10.1002/2015JF003806

Clague, J.J., Ward, B., 2011. Pleistocene glaciation of British Columbia. In Developments in Quaternary Sciences 15. Ehlers, J., Gibbard, P.L., Hughes, P.D. (Eds.) Elsevier. pp. 563-573. ISBN: 978-0-444-53447-7.

Clark, C.D., Stokes, C.R., 2003. The palaeo-Ice Stream Landsystem. In Evans, D.J.A. (Ed.), Glacial Landsystems (pp. 204-227): Arnold, London. https://doi.org/10.1002/ jqs.826.

Cohen, D., Gillet-Chaulet, F., Haeberli, W., Machguth, H., Fischer, U.H., 2018. Numerical reconstructions of the flow and basal conditions of the Rhine glacier, European Central Alps, at the Last Glacial Maximum. The Cryosphere, 12, 2515-2544. https://doi.org/10.5194/tc-122515-2018

Cowan, E.A., Christoffersen, P., Powell, R.D., 2012. Sedimentological signature of a deformable bed preserved beneath an ice stream in a Late Pleistocene glacial sequence, Ross Sea, Antarctica. Journal of Sedimentary Research, 82, 270-282. https://doi.org/10.2110/jsr.2012.25

Cowan, E. A., Christoffersen, P., Powell, R. D., Talarico, F.M., 2014. Dynamics of the late Plio-Pleistocene West Antarctic Ice Sheet documented in subglacial diamictites, AND-1B drill core. Global and Planetary Change, 119(Supplement C), 56-70. https://doi.org/10.1016/j. gloplacha.2014.05.011

Davies, D., Bingham, R.G., King, E.C., Smith, A.M., Brisbourne, A.M., Spagnolo, M., Graham, A.G.C., Hogg, A.E., Vaughan, D.G., 2018. How dynamic are ice-stream beds? The Cryosphere, 12, 1615-1628. https://doi.org/10.5194/ tc-12-1615-2018

Diez, A., Matsuoka, K., Ferraccioli, F., Jordan, T.A., Corr, H.F., Kohler, J., Olesen, A.V., Forsberg, R., 2018. Basal settings control fast ice flow in the Recovery/Slessor/Bailey Region, East Antarctica. Geophysical Research Letters 45, 2706-2715. https://doi.org/10.1002/2017GL076601

Dowdeswell, J.A., Elverhøi, A., 2002. The timing of initiation of fast-flowing ice streams during a glacial cycle inferred from glaciomarine sedimentation. Marine Geology 188, 3-14 https://doi.org/10.1016/S00253227(02)00272-4

Ehlers, J., Gibbard, P.L., Hughes, P.D., 2011. Supplementary data to Quaternary glaciations - extent and chronology, a closer look. Developments in Quaternary Science 15, Elsevier, Amsterdam. https://booksite.elsevier. com/9780444534477

Eyles, N., Arbelaez Moreno, L., Sookhan, S., 2018. Ice streams of the Late Wisconsin Cordilleran Ice Sheet in western North America. Quaternary Science Reviews 179, 87-122. https://doi.org/10.1016/j.quascirev.2017.10.027

Evans, D.J., 2017. Till: A glacial process sedimentology. John Wiley and Sons. 400pp. ISBN - 9781118652596.

Evans, D., Phillips, E., Hiemstra, J., Auton, C., 2006. Subglacial till: formation, sedimentary characteristics and classification. Earth-Science Reviews 78, 115-176.

https://doi:10.1016/j.earscirev.2006.04.001
Evenson, E.B., 1971. The relationship of macro- to microfabrics of tills and the genesis of glacial landforms in Jefferson County, Wisconsin. In: Goldthwait, R.P. (Ed.), Till, a symposium. Ohio State University Press, Columbus, pp. 345-364.

Eyles, N., Arbelaez Moreno, L., Sookhan, S., 2018. Ice streams of the Late Wisconsin Cordilleran Ice Sheet in western North America. Quaternary Science Reviews 179, 87-122. https://doi.org/10.1016/j.quascirev.2017.10.027

Fossen, H., Soliva, R., Ballas, G., Trzaskos, B., Cavalcante, C., Schultz, R.A., 2017. A

Review of Deformation Bands in Reservoir Sandstones: Geometries, Mechanisms and

Distribution, vol. 459 Geological Society, London, Special Publications SP459.4.

https://doi.org/10.1144/SP459.4

Fossen, H., Cavalcante, G. C. G., Pinheiro, R. V. L., Archanjo, C., J. 2019. Deformation-progressive or multiphase? Journal of Structural Geology 125, 82-99. https://doi. org/10.1016/j.jsg.2018.05.006

Gao, C., McAndrews, J.H., Wang, X., Menzies, J., Turton, C.L., Wood, B.D., Pei, J., Kodors, C., 2012. Glaciation of North America in the James Bay Lowland, Canada, 3.5 Ma. Geology 40, 975-978. https://doi:10.1130/G33092.1

Haeberli, W., Penz, U., 1985. An attempt to reconstruct glaciological and climatological characteristics of 18 ka BP Ice Age glaciers in and around the Swiss Alps. Zeitschrift für Gletscherkunde und Glazialgeologie, 21, 351-361.

Halberstadt, A.R.W., Simkins, L.M., Anderson, J.B., Prothro, L.O., Bart, P.J., 2018. Characteristics of the deforming bed: till properties on the deglaciated Antarctic continental shelf. Journal of Glaciology, 1-14. https:// doi: 10.1017/jog.2018.92

Hart, J.K., Martinez, K., Basford, P.J., Clayton, A.I., Robson, B.A., Young, D.S., 2019. Surface melt driven summer diurnal and winter multi-day stick-slip motion and till sedimentology. Nature communications 10, 1-11. https:// doi: 10.1038/s41467-019-09547-6

Hiemstra, J.F., van der Meer, J.J.M., 1997. Pore-water controlled grain fracturing as indicator for subglacial shearing in tills. Journal of Glaciology 43: 446-454. https://doi. org/10.3189/S0022143000035036

Hoffmann, K., Piotrowski, J. A., 2001. Till melange at Amsdorf, central Germany; sediment erosion, transport and deposition in a complex, soft-bedded subglacial system. Sedimentary Geology 140, 215-234. https://doi. org/10.1016/S0037-0738(00)00184-6

Keller, B., 1996. Lithofazies-Codes für die Klassifikation von Lockergesteinen. Mitteilungen der Schweizerischen Gesellschaft für Boden- und Felsmechanik 132, 5-12.

Klasen, N., Fiebig, M., Preusser, R., Reitner, J.M., Radtke, U., 2007. Luminescence dating of proglacial sediments from the Eastern Alps. Quaternary International 164165, 21-32. https://doi:10.1016/j.quaint.2006.12.003

Lee, J.R., Phillips, E.R., 2008. Progressive soft sediment deformation within a subglacial shear zone-a hybrid 
mosaic-pervasive deformation model for Middle Pleistocene glaciotectonised sediments from eastern England. Quaternary Science Reviews 27, 1350-1362. https://doi.org/10.1016/j.quascirev.2008.03.009

Lindgren, A., Hugelius, G., Kuhry, P., Christensen, T.R., Vandenberghe, J., 2016. GIS-based Maps and Area Estimates of Northern Hemisphere Permafrost Extent during the Last Glacial Maximum. Permafrost and Periglacial Processes 27, 6-16. https://doi.org/10.1002/ppp.1851

Linner, M., Reitner, J. M., Pavlik, W., 2013. Geologische Karte der Republik Österreich 1:50.000 Blatt 179 Lienz, Geologische Bundesanstalt, Wien.

Margold, M., Jansson, K.N., Kleman, J., Stroeven, A.P., Clague, J.J., 2013. Retreat pattern of the Cordilleran Ice Sheet in central British Columbia at the end of the last glaciation reconstructed from glacial meltwater landforms. Boreas 42, 830-847. http://dx.doi.org/10.1016/j. quascirev.2014.06.027

Menzies, J., 1990. Sand Intraclasts within a diamicton mélange, southern Niagara Peninsula, Ontario, Canada. Journal of Quaternary Science 5, 189-206.

Menzies, J., 2000. Micromorphological analyses of microfabrics and microstructures, indicative of deformation processes, in glacial sediments. In: Maltman, A.J. Hubbard, B., Hambrey, M.J. (Eds.), Deformation of Glacial Materials. Geological Society, London. pp. 245-258. https:// doi.org/10.1144/GSL.SP.2000.176.01.19

Menzies, J., 2012. Strain pathways, till internal architecture and microstructures - perspectives on a general kinematic model - a 'blueprint' for till development. Quaternary Science Reviews 50, 105-124. https://doi.10.1016/j. quascirev.2012.07.012

Menzies, J., van der Meer, J.J.M., 2018. Micromorphology and Microsedimentology of Glacial Sediments Chapter 21. In: Menzies, J., van der Meer, J.J.M. (Eds.), Past Glacial Environments (Second Edition). Elsevier, pp. 753-806. https://doi.org/10.1016/B978-0-08-100524-8.00036-1

Menzies, J., Reitner, J.M., 2016. Microsedimentology of ice stream tills from the Eastern Alps, Austria-a new perspective on till microstructures. Boreas 45, 804-827. https://doi.org/10.1111/bor.12189

Menzies, J., Reitner, J.M., 2019. Microstructures, subglacial till deposition, and shear band development revealing up-section changes in shear-A study from Weissbach, Austria. Proceedings of the Geologists' Association 130/2, 196-209. https://doi.org/10.1016/j.pgeola.2018.11.001

Menzies, J., Gao, C., Kodors, C., 2013. Microstructural analyses of a Middle Pliocene till from the James Bay Lowlands, Canada-evidence of "potential" fast ice streaming. Proceedings of the Geologists' Association 124, 790-801. http://dx.doi.org/10.1016/j.pgeola.2012.07.002

Menzies, J., van der Meer, J.J.M., Ravier, E., 2016. A kinematic unifying theory of microstructures in subglacial tills. Sedimentary Geology 344, 57-70. http://dx.doi. org/10.1016/j.sedgeo.2016.03.024
Monegato, G., Ravazzi, C., Donegana, M., Pini, R., Calderoni, G., Wick, L., 2007. Evidence of a two-fold glacial advance during the last glacial maximum in the Tagliamento end moraine system (eastern Alps). Quaternary Research 68, 284-302. https://doi.org/10.1016/j. yqres.2007.07.002

Narloch, W., Phillips, E.R., Piotrowski, J.A., Ćwiek, M., 2020. Patterns of deformation within a subglacial shear zone: Implications for palaeo-ice stream bed evolution. Sedimentary Geology 39, 105569. https://doi.org/10.1016/j. sedgeo.2019.105569

Passchier, C.W., Trouw, R.A.J., 1996. Micro-tectonics. Berlin-Heidelberg, Germany: Springer Verlag. 289pp. ISBN10 3-540-64003-7

Philit, S., Soliva, R., Castilla, R., Ballas, G., Taillefer, A., 2018. Clusters of cataclastic deformation bands in porous sandstones. Journal of Structural Geology 114, 235-250. https://doi.org/10.1016/j.jsg.2018.04.013

Phillips, E., 2006. Micromorphology of a debris flow deposit: evidence of basal shearing, hydrofracturing, liquefaction and rotational deformation during emplacement. Quaternary Science Reviews 25, 720-738. https:// doi.org/10.1016/j.quascirev.2005.07.004

Phillips, E., van der Meer, J.J.M., Ferguson, A., 2011. A new 'microstructural mapping' methodology for the identification, analysis and interpretation of polyphase deformation within subglacial sediments. Quaternary Science Reviews 30, 2570-2596.

http://dx.doi.org/10.1016/j.quascirev.2011.04.024

Phillips, E., Spagnolo, M., Pilmer, A.C., Rea, B.R., Piotrowski, J.A., Ely, J.C., Carr, S., 2018. Progressive ductile shearing during till accretion within the deforming bed of a palaeo-ice stream. Quaternary Science Reviews 193, 1-23. https://doi.org/10.1016/j.quascirev.2018.06.009

Piotrowski, J.A., Larsen, N.K., Junge, F.W., 2004. Reflections on soft subglacial beds as a mosaic of deforming and stable spots. Quaternary Science Reviews 23, 993-1000. http://dx.doi.org/10.1016/j.quascirev.2004.01.006

Prothro, L.O., Simkins, L.M., Majewski, W., Anderson, J.B., 2018. Glacial retreat patterns and processes determined from integrated sedimentology and geomorphology records. Marine Geology 395,104-119. https://doi. org/10.1016/j.margeo.2017.09.012

Reinardy, B., 2012. Streaming flow of an Antarctic Peninsula palaeo-ice stream by both basal sliding and deformation of substrate. Quaternary International 279-280, 397. https://doi.org10.1016/j.quaint.2012.08.1253

Reinardy, B.T., Larter, R.D., Hillenbrand, C.-D., Murray, T., Hiemstra, J.F., Booth, A.D., 2011. Streaming flow of an Antarctic Peninsula palaeo-ice stream, both by basal sliding and deformation of substrate. Journal of Glaciology 57, 596-608. https://doi.org/10.3189/002214311797409758 Reitner, J., 2003. Bericht 1998/1999 über geologische Aufnahmen im Quartär auf Blatt 179 Lienz. Jahrbuch der Geologischen Bundesanstalt, 143/3, 516-524.

Reitner, J.M., 2005. Quartärgeologie und Landschaftsentwicklung im Raum Kitzbühel -St.Johann i.T.-Hopfgarten (Nordtirol) vom Riss bis in das Würm-Spätglazial (MIS 
6-2). Doctoral Thesis, Universität Wien, Vienna, Austria, 190pp. https://doi.org/10.13140/rg.2.1.2505.6405

Reitner J.M., 2007. Glacial dynamics at the beginning of Termination I in the Eastern Alps and their stratigraphic implications. Quaternary International 164-165, 64-84. https://doi.org/10.1016/j.quaint.2006.12.016

Reitner, J.M., Linner, M., 2009. Formation and preservation of large scale toppling related to alpine tectonic structures-Eastern Alps. Austrian Journal of Earth Sciences 102, 69-80

Reitner, J.M., Gruber, W., Römer, A., Morawetz, R., 2010. Alpine overdeepenings and paleo-ice flow changes: an integrated geophysical-sedimentological case study from Tyrol (Austria). Swiss Journal of Geoscience 103, 385-405. https://doi.org/10.1007/s00015-010-0046-9

Reitner, J.M., Ivy-Ochs, S., Drescher-Schneider, R., Hajdas, I., Linner, M., 2016. Reconsidering the current stratigraphy of the Alpine Lateglacial: Implications of the sedimentary and morphological record of the Lienz area (Tyrol/Austria). E\&G Quaternary Science Journal 65, 113-144. https://doi.org/10.3285/eg.65.2.02

Rice, J.M., Paulen, R.C., Menzies, J., McClenaghan, M.B., 2014. Micromorphological descriptions of till from pit K-62, Pine Point mining district, Northwest Territories; Geological Survey of Canada, Open File 7526, 30 p. https://doi:10.4095/293478

Rice, J., Menzies, J., Paulen, R.C., McClenaghan, M.B., 2018. Microsedimentological evidence of vertical fluctuations in subglacial stress from the northwest sector of the Laurentide Ice Sheet, Northwest Territories, Canada. Canadian Journal of Earth Sciences 56, 363-379. https:// doi:10.1139/cjes-2018-0201

Seguinot, J., Rogozhina, I., Stroeven, A.P., Margold, M., Kleman, J., 2016. Numerical simulations of the Cordilleran ice sheet through the last glacial cycle. The Cryosphere 10, 639-664. https://doi:10.5194/tc-10-639-2016

Seguinot, J., Ivy-Ochs, S., Jouvet, G., Huss, M., Funk, M., Preusser, F., 2018. Modelling last glacial cycle ice dynamics in the Alps. The Cryosphere 12, 3265-3285. https:// doi.org/10.5194/tc-12-3265-2018

Schoneveld, C., 1977. A study of some typical inclusion patterns in strongly paracrystalline-rotated garnets. Tectonophysics 39, 453-471

Schultz, R., Siddharthan, R., 2005. A general framework for the occurrence and faulting of deformation bands in porous granular rocks. Tectonophysics 411, 1-18. https://doi.org/10.1016/j.tecto.2005.07.008

Simpson, C., De Paor, D.G., 1993. Strain and kinematic analysis in general shear zones. Journal of Structural Geology 15, 1-20.

Smith, A.M., Jordan, T.A., Ferraccioli, F., Bingham, R.G., 2013. Influence of subglacial conditions on ice stream dynamics: Seismic and potential field data from Pine Island Glacier, West Antarctic. Journal of Geophysical Research 118, 1471-1482, https://doi.org/10.1029/ 2012JB009582

Spagnolo, M., Phillips, E., Piotrowski, J.A., Rea, B.R., Clark, C.D., Stokes, C.R., Carr, S.J., Ely, J.C., Ribolini, A., Wysota,
W., Szuman, I., 2016. Ice stream motion facilitated by a shallow-deforming and accreting bed. Nat Commun 7, 11p. https://doi.org/10.1038/ncomms10723

Stokes, C.R., 2011. Palaeo-ice stream. In: Encyclopedia of Snow, Ice and Glaciers.

Springer, Dordrecht, Netherlands, pp. 127-128. ISBN 97890-481-2642-2

Stokes, C.R., 2018. Geomorphology under ice streams: Moving from form to process. Earth Surface Processes and Landforms 43, 85-123. https://doi.org/10.1002/ esp.4259

Stumpf, A.J., Broster, B.E., Levson, V.M., 2000. Multiphase flow of the late Wisconsinan cordilleran ice sheet in western Canada. Geol. Soc. Am. Bull. 112, 1850-1863.

https://doi.org/10.1130/0016-7606(2000)112<1850:MFOTLW $>2.0 . C O ; 2$

Swift, D.A., Cook, S.J., Graham, D.J., Midgley, N.G., Fallick, A.E., Storrar, R., Toubes Rodrigo, M., Evans, D.J.A., 2018. Terminal zone glacial sediment transfer at a temperate overdeepened glacier system. Quaternary Science Reviews 180, 111-131. https://doi.org/10.1016/j.quascirev.2017.11.027

Thomason, J.F., Iverson, N.R., 2006. Microfabric and microshear evolution in deformed till. Quaternary Science Reviews 25, 1027-1038. https://doi.org/10.1016/j.quascirev.2005.09.006.

van der Meer, J.J.M., 1993. Microscopic evidence of subglacial deformation. Quaternary Science Reviews 12, 553-587.

van der Meer, J.J.M., 1996. Micromorphology. In: Menzies, J (Ed.), Past Glacial Environments - sediments, forms and techniques. Butterworth-Heineman, Oxford. Chapter 12, pp. 335-356. ISBN: 0750623527.

van der Meer, J.J.M., 1997. Particle and aggregate mobility in till: microscopic evidence of subglacial processes. Quaternary Science Reviews 16, 827-831.

van der Meer, J.J.M., Menzies, J. 2011. The micromorphology of unconsolidated sediments. Sedimentary Geology 238, 213-232. https://doi.org/210.210.216/j. sedgeo.2011

van Husen, D., 1977. Zur Fazies und Stratigraphie der jungpleistozänen Ablagerungen im Trauntal. Jahrbuch der Geologischen Bundesanstalt, 120/1, 1-130.

van Husen, D., 1987. Die Ostalpen in den Eiszeiten. Geologische Bundesantalt. 27pp.

van Husen, D., 2000. Geological processes during the Quaternary. Mitteilungen der Österreichischen Geologischen Gesellschaft 92(1999), 135-156. ISSN 0251-7493 van Husen, D., Reitner, J.M., 2011. An Outline of the Quaternary Stratigraphy of Austria. E\&G - Quaternary Science Journal 60, 366-387. https://doi.org/10.3285/ eg.60.2-3.09

Vaughan-Hirsch, D.P., Phillips, E., Lee, J.R., Hart, J.K., 2013. Micromorphological analysis of poly-phase deformation associated with the transport and emplacement of glaciotectonic rafts at West Runton, north Norfolk, UK. Boreas 42, 376-394. https://doi.org/10.1111/j.15023885.2012.00268.x 
Walter, F., Chaput, J., Lüthi, M.P., 2014. Thick sediments beneath Greenland's ablation zone and their potential role in future ice sheet dynamics. Geology 42, 487-490. https://doi.org/10.1130/G35492.1

Winsborrow, M.C.M., Clark, C.D., Stokes, C.R., 2010. What controls the location of ice streams? Earth-Science Reviews 103, 45-59. https://doi.org/10.1016/j.earscirev.2010.07.003
Wirsig, C., Zasadni, J., Christl, M., Akçar, N., Ivy-Ochs, S., 2016. Dating the onset of LGM ice surface lowering in the High Alps. Quaternary Science Reviews 143, 37-50. https://doi.org/10.1016/j.quascirev.2016.05.001

Received: 18.12.2019

Accepted: 26.3.2020

Editorial handling: Kurt Stüwe 